\title{
Two new genera of Acanthaceae from tropical Africa
}

\author{
lain Darbyshire ${ }^{1}$, Carrie A. Kiel ${ }^{2}$, Thomas F. Daniel ${ }^{3}$, Lucinda A. McDade ${ }^{2}$ \& W. R. Quentin Luke ${ }^{4}$
}

Summary. DNA sequence data, macro-morphological evidence and pollen analysis are used to clarify the phylogenetic placement of two African species of Acanthaceae: Schaueria populifolia C.B.Clarke and Rhinacanthus ndorensis Schweinf. The combined data demonstrate that these species are only distantly related to the genera in which they are currently placed and provide strong support for recognition of new genera to accommodate them. Two new genera are therefore proposed and a taxonomic account is provided for each of these. The first, Champluviera I.Darbysh., T.F.Daniel \& C.A.Kiel, is based primarily on S. populifolia but Chlamydocardia nuda C.B.Clarke (= Justicia tigrina Heine) is also included within this new genus based on shared morphological traits, at least one of which is synapomorphic and restricted to these species. Based on molecular evidence, Champluviera is placed in a well-supported clade of several genera that are together sister to the core Isoglossinae lineage of tribe Justicieae. The genus may be recognised morphologically by the combination of a dense spiciform terminal thyrse with the bracts, bracteoles and calyx lobes all slender and closely resembling one another; a bilabiate corolla lacking a rugula and with intricate speckling or striping on the lips; and, in particular, the putatively synapomorphic trait of anther thecae with broad, flattened, basal appendages that have an irregularly toothed fringe. The second new genus, Kenyacanthus I.Darbysh. \& C.A.Kiel, is based on R. ndorensis and is so far thought to be monospecific. It is placed between core Diclipterinae and Monechma Group II within the expanded subtribe Diclipterinae in tribe Justicieae. Kenyacanthus can be recognised morphologically by having the combination of a trailing or procumbent habit; fasciculate inflorescences; bracts, bracteoles and calyces with hyaline margins; a bilabiate corolla with a slender cylindrical tube longer than the limb and with a shallow rugula; stenotribic flowers, with the stamens held against the lower lip; and anthers with only slightly offset thecae that lack appendages.

Key Words. Floristics, justicioid, phylogeny, taxonomy.

\section{Introduction}

With at least 2000 species and a nearly worldwide distribution, the Justicieae lineage of the Acanthaceae has long challenged taxonomists. Considerable progress has been made in the last 20 years in understanding this, the largest of the major lineages of Acanthaceae. However, recent phylogenetic work (e.g., Kiel et al. 2006, 2017; Daniel et al. 2008; McDade et al. 2000, 2018), as well as floristic and taxonomic research (e.g., Côrtes et al. 2016; Daniel 1995a, 2015, 2017; Darbyshire \& Govaerts 2017; Darbyshire \& Goyder 2019), has pointed to a number of outstanding problems that require resolution. Here, we propose solutions for two such taxonomic problems involving the African plants Schaueria populifolia C.B.Clarke and Rhinacanthus ndorensis Schweinf.

\section{Schaueria populifolia}

The genus Schaueria Nees (1839: 3) was originally described from the forests of eastern Brazil, and is best known for the species S. calytricha (Hook.)
A.L.A.Côrtes ("golden plume"), which is popular in botanical gardens (Côrtes et al. 2016). Schaueria is a member of the "Tetramerium lineage" of the tribe Justicieae (Daniel et al. 2008; Côrtes et al. 2016; McDade et al. 2018). The genus is exclusively New World (NW) in distribution with the notable exception of S. populifolia C.B.Clarke (1900a: 242), which is found in the lowland rainforests of eastern Nigeria, Bioko and western and southern Cameroon. Daniel et al. (2008) noted that there are otherwise no genera of the Tetramerium lineage common to both the Old World (OW) and NW. As such, it would be remarkable if this African species were indeed a Schaueria.

A recent taxonomic revision of Schaueria by Côrtes et al. (2016), using both molecular and morphological evidence, demonstrated that Schaueria s.l. is polyphyletic. As a result, six species traditionally included in Schaueria were excluded following a recircumscription of the genus. The 14 species of Schaueria treated in the revision are all restricted to Brazil (Côrtes et al. 2016).

\footnotetext{
Accepted for publication 25 June 2019. Published online 9 September 2019

1 Royal Botanic Gardens, Kew, Richmond, Surrey, TW9 3AB, UK. e-mail: i.darbyshire@kew.org

2 Rancho Santa Ana Botanic Garden, Claremont Graduate University, 1500 North College Avenue, Claremont, CA, 91711, USA.

3 California Academy of Sciences, 55 Music Concourse Drive, San Francisco, CA, 94118, USA.

4 East African Herbarium, National Museums of Kenya, P.O. Box 45166, Nairobi, 00100, Kenya.
} 
Schaueria populifolia was not included in these authors' molecular studies, but they rejected this species from Schaueria on the basis that then unpublished molecular data by L. McDade show that $S$. populifolia is more closely related to the Isoglossinae lineage than to the Tetramerium lineage. These data have subsequently been published in an expanded sampling of the Tetramerium lineage based on six gene regions (McDade et al. 2018). These authors showed that S. populifolia, represented by Gereau et al. 5666 (MO) from Cameroon, was resolved with taxa of Isoglossinae that were sampled as outgroups. However, the authors noted that taxon sampling among outgroups was insufficient for the results to be considered conclusive regarding the placement of $S$. populifolia.

Côrtes et al. (2016) did not comment on any morphological differences between Schaueria s.s. and S. populifolia. The two are superficially similar, sharing many-flowered inflorescences comprising a series of dichasial inflorescence units; long narrow bracts, bracteoles and calyx lobes; a bilabiate corolla lacking a rugula (stylar furrow); two bithecous stamens and stipitateclavate 4-seeded capsules with tuberculate seeds. However, these similarities are symplesiomorphic or of uncertain phylogenetic status and thus do not constitute evidence of a close relationship.

\section{Rhinacanthus ndorensis}

Rhinacanthus ndorensis was described by Schweinfurth (1892) from Ndoro near Mt Kenya. It is restricted to central Kenya where it occurs in grassland and open woodland, typically on seasonally damp black clay soils (Darbyshire et al. 2010). The species was maintained within the genus Rhinacanthus Nees for the Flora of Tropical East Africa account of Acanthaceae (Darbyshire et al. 2010) and for related studies on the genus in Africa (Darbyshire \& Harris 2006), primarily on the basis of the slender corolla tube that is longer than the lips and the anther thecae of each stamen being offset and basally muticous. However, keys to the species of Rhinacanthus presented in those publications identify $R$. ndorensis first due to a number of unique characters including its procumbent or trailing habit, fasciculate inflorescences, hyaline margins to the bracts, bracteoles and calyx lobes and essentially glabrous capsules.

In a phylogenetic study of the 'justicioid' lineage of Justicieae based on six gene regions, Kiel et al. (2017) sampled one voucher of Rhinacanthus ndorensis (Young 3169, EA) together with 10 other accessions of Rhinacanthus representing eight additional species. They found that all sampled Rhinacanthus are resolved in an expanded Diclipterinae lineage, but that Rhinacanthus s.l. is not monophyletic (Kiel et al. 2017, Fig. 8). These authors recognised a well-supported Rhinacanthus clade comprising seven of the nine species sampled. However, they found that two species of the genus fall outside this clade: $R$. virens (Nees) Milne-Redh. and $R$. ndorensis. The former, a GuineoCongolian forest species of West Africa, was placed basally among members of the Diclipterinae lineage; it is tentatively maintained in Rhinacanthus whilst we await further molecular investigation of this species and the other forest species of Rhinacanthus (Darbyshire et al. 2018). The latter was placed sister to core Diclipterinae, a lineage that comprises Dicliptera Juss., Peristrophe Nees (sometimes treated as congeneric with Dicliptera; Darbyshire \& Vollesen 2007), Xerothamnella C.T.White and Hypoestes R.Br.

For this study, we combine macro-morphological data, pollen analysis and DNA sequence data for Schaueria populifolia and Rhinacanthus ndorensis with the goal of clarifying the phylogenetic placement of these two taxa. With regard to the former, we test the hypothesis that this African species is not related to its American congeners in the context of a more expansive sample of OW taxa that was included in earlier studies. Regarding Rhinacanthus, we seek to test the hypothesis that $R$. ndorensis is not closely related to Rhinacanthus s.s.

\section{Materials \& Methods}

\section{Morphological Analysis}

Herbarium specimens of the focal taxa and related groups held at the $\mathrm{BM}, \mathrm{K}, \mathrm{MO}$ and $\mathrm{P}$ herbaria were examined, supported by study of digital images of specimens from the BR, L, LBV and WAG herbaria accessed via their respective online catalogues or by individual request. Abbreviations for herbaria follow Index Herbariorum (Thiers 2019). All duplicates of specimens seen are marked in the "Specimens Examined" sections with an exclamation mark (!). Those for which only online images have been seen are marked with an asterisk (*). The herbarium research was supplemented by field studies and photographs of wild plants where possible.

All measurements were made on dried material except for those of the flowers. Dried flowers were soaked in Aerosol OT 5\% solution prior to dissection and measurement.

\section{Pollen analysis}

For the study of pollen of Schaueria populifolia, individual grains were removed from multiple anthers on the specimen Cheek 7771 using an insect pin. The grains were mounted onto a SEM stub coated with double-sided sticky tape, sputter coated with gold/palladium and examined under SEM at CAS. Study of pollen of Rhinacanthus ndorensis followed a similar methodology except that a whole anther was extracted from a flower bud on Luke 17084 and 
dissected to extract the pollen. Also in this case, the SEM stub was sputter coated with platinum before examination under SEM at K.

\section{Molecular analysis}

For this study, new sequence data were generated for nine taxa (Appendix 1). These were supplemented by downloading data for an additional 94 accessions from GenBank (Appendix 1). Most of these latter data were generated for previous studies in Justicieae (McDade et al. 2000, 2008, 2018; Kiel et al. 2006, 2017; Daniel et al. 2008).

To make the datasets congruent across the five loci sampled, we sequenced an additional 94 samples (Appendix 1) for the final dataset totalling 103 taxa. For the newly generated sequences, leaf tissue was extracted using Doyle \& Doyle's (1987) CTAB method. Procedures to amplify the cp $t r n T-L, t r n L-F$ and $t r n S-G$ spacers, and rps16 intron were as described by Daniel et al. (2008). Procedures for amplification of nrITS are found in McDade et al. (2000) and Daniel et al. (2008). PCR products were cleaned using PEG precipitation (Morgan \& Soltis 1993) and the purified PCR products were cycle sequenced with both forward and reverse PCR primers using Applied Biosystems (ABI, Foster City, California) PRISM BigDye version 3.1, according to the manufacturer's specifications. All sequenced reactions were cleaned with Sephadex G50 and sequenced on an ABI 3100 genetic analyzer. Chromatograms were edited and aligned manually in Geneious ${ }^{\circledR}$ version 9.15 (https:// www.geneious.com) and alignments were deposited in TreeBASE, 23681.

Data matrices for the five DNA regions were prepared as nexus files for Maximum Likelihood and Bayesian analyses in Geneious 9.1.5. Possible incongruence between the nrITS and $\mathrm{cp}$ data sets was examined by comparing the results of majority rule trees from Bayesian inference (analyses conducted as described below). We used a posterior probability value of 0.90 as a conservative threshold for wellsupported conflict. Finding no evidence of incongruence between nrITS and cp data, we combined the datasets for further analyses.

Bayesian inference (BI) of phylogenetic relationships with posterior probabilities (BPP) as the support measure was conducted in MrBayes 3.2.6 (Huelsenbeck \& Ronquist 2001; Huelsenbeck et al. 2001; Ronquist \& Huelsenbeck 2003). Models of molecular evolution for the genic regions were selected using the Akaike information criterion (AIC) (Akaike 1974; Posada \& Crandall 2001) as implemented in JModelTest 2.1.3 (Posada 2008; Darriba et al. 2012). The selected models of nucleotide substitution were GTR + G for the combined plastid dataset and $\mathrm{GTR}+\mathrm{G}+\mathrm{I}$ for nrITS. Each dataset was run with data partitions corresponding to the combined cp and nrITS regions. Two simultaneous runs of four Monte Carlo Markov Chains were run for 20,000,000 generations with a random tree as the starting point and saving trees every 1,000 generations. Results were inspected in Tracer version 1.5 (Rambaut et al. 2014) to determine the burn-in period. Analysis of the nuclear $+\mathrm{cp}$ dataset reached stationarity (i.e., average standard deviation of split frequencies $\leq 0.01$ ) after approximately 5,000,000 generations and the first $20 \%$ of the sampled trees were discarded as burn-in before constructing a majority rule consensus tree.

The three data sets (i.e. cp, nrITS, cp + nrITS) were also analysed using maximum likelihood (ML) using RAxML ver. 8.0.0 (Stamatakis 2014). For analysis, the combined data were partitioned under the same models of evolution as used for Bayesian inference, and 1000 bootstrap replicates were implemented. Each analysis was repeated three times to test the consistency of tree topology and bootstrap values (MLBS).

\section{Species conservation (extinction risk) assessments}

The species conservation assessments are based on the Categories and Criteria of the IUCN Red List (2012). The Extent of Occurrence (EOO) was calculated using the Kew Geospatial Conservation Assessment Tool GeoCAT (geocat.kew.org; Bachman et al. 2011).

\section{Results}

The topologies returned by BI and ML are congruent and are also congruent with the results of all earlier studies of Justicieae (e.g., McDade et al. 2000, 2018; Kiel et al. 2006, 2017; Daniel et al. 2008; Côrtes et al. 2016). We emphasise here the placement of the two focal taxa and do not reiterate the relationships established in earlier studies, a more complete review of relationships within Justicieae will be presented in a forthcoming paper (Kiel et al. in prep).

The three accessions of Schaueria populifolia (Fig. 1) are together monophyletic with strong support (1.00 BPP; 100 MLBS); this clade is in turn part of a wellsupported clade (1.00 BPP; 100 MLBS) of several genera that are together sister with weak support $(0.75$ BBP; 51 MLBS) to the core Isoglossinae lineage (1.00 BPP; 100 MLBS) (Fig. 1). Accessions of Schaueria s.s. are placed phylogenetically distant from $S$. populifolia in the Tetramerium lineage (Fig. 1).

Two accessions of Rhinacanthus ndorensis (Fig. 2) are sister with strong support (1.00 BPP; 99 MLBS) and are together sister to Dicliptera s.l. + Hypoestes with strong support for this relationship (1.00 BPP; 100 MLBS). Rhinacanthus virens is a member of a weakly supported basal lineage (0.96 BPP; $56 \mathrm{MLBS})$ in Diclipterinae and is sister to Justicia aff. tenuipes with strong support (1.00 BPP; 98 MLBS). All other sampled Rhinacanthus are members of the core Rhinacanthus clade (1.00 BPP; $88 \mathrm{MLBS}$ ) and are not closely related to $R$. ndorensis (Fig. 2). 


\section{Justicieae}

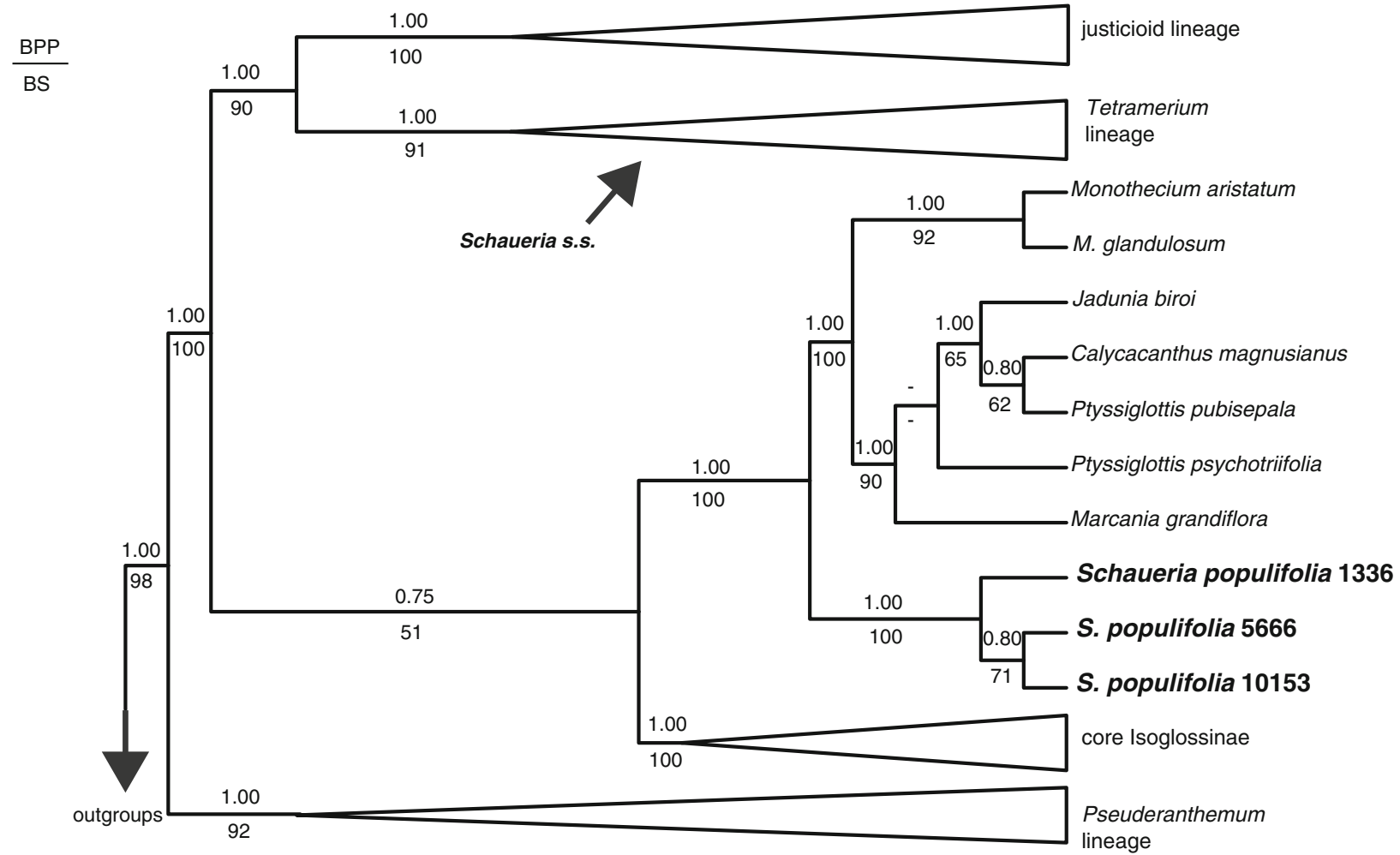

Fig. 1. Summary of phylogenetic relationships among Justicieae highlighting Schaueria populifolia (= Champluviera populifolia) from Maximum likelihood. BPP = values above branch and MLBS = values below branch .

Analysis of DNA sequence data thus supports recognition of two new genera to accommodate Schaueria populifolia and Rhinacanthus ndorensis. Supporting evidence from the morphological analyses, including pollen, will be described in detail in the Discussion below.

\section{Discussion and taxonomic treatments}

\section{Champluviera - a new genus from the forests of central Africa}

Our study of specimens of Schaueria populifolia found notable morphological differences between plants of this African species and Brazilian congeners. Brazilian Schaueria (henceforth Schaueria s.s.) have white or yellow flowers lacking speckling, whilst those of S. populifolia are dull red, red-brown or purple with intricate speckling on at least the lower lip (Fig. 3). More significantly, in Schaueria s.s., the anther thecae of each stamen lack basal appendages and are glabrous, whereas those of $S$. populifolia have a broad, flattened and irregularly fringed basal appendage and the upper theca has a fringe of trichomes on the margin that is not adpressed to the second theca.
Pollen of Schaueria populifolia is remarkable in that the ora are markedly enlarged in comparison to the colpi and the two pseudocolpi in each mesocolpium curve toward one another equatorially and sometimes fuse at the equator, forming an hour-glass shape or figure eight (Fig. 4). In contrast, pollen of Schaueria s.s. have ora that are less markedly enlarged and the pseudocolpi are \pm parallel to the apertures such that the two pseudocolpi of each mesocolpium do not form an hour-glass shape (see Côrtes et al. 2016, Fig. 6).

These morphological differences indicate that the resemblance between Schaueria s.s. and S. populifolia is superficial and that they are not closely related, thus supporting the findings of the molecular analysis (Fig. 1).

On studying specimens of Schaueria populifolia during her research on the Acanthaceae of West and Central Africa, Dominique Champluvier (formerly of BR) proposed the new combination Justicia populifolia (C.B.Clarke) Champl. and annotated specimens at the Kew herbarium as such in April 1999. This name was adopted by Onana $(2011,2013)$ as an unpublished combination in the checklist of vascular plants of Cameroon, but has never been validly published. This new combination was proposed on the basis that the flowers, and in particular the unique appendages of the anthers described above, bear a close resemblance 


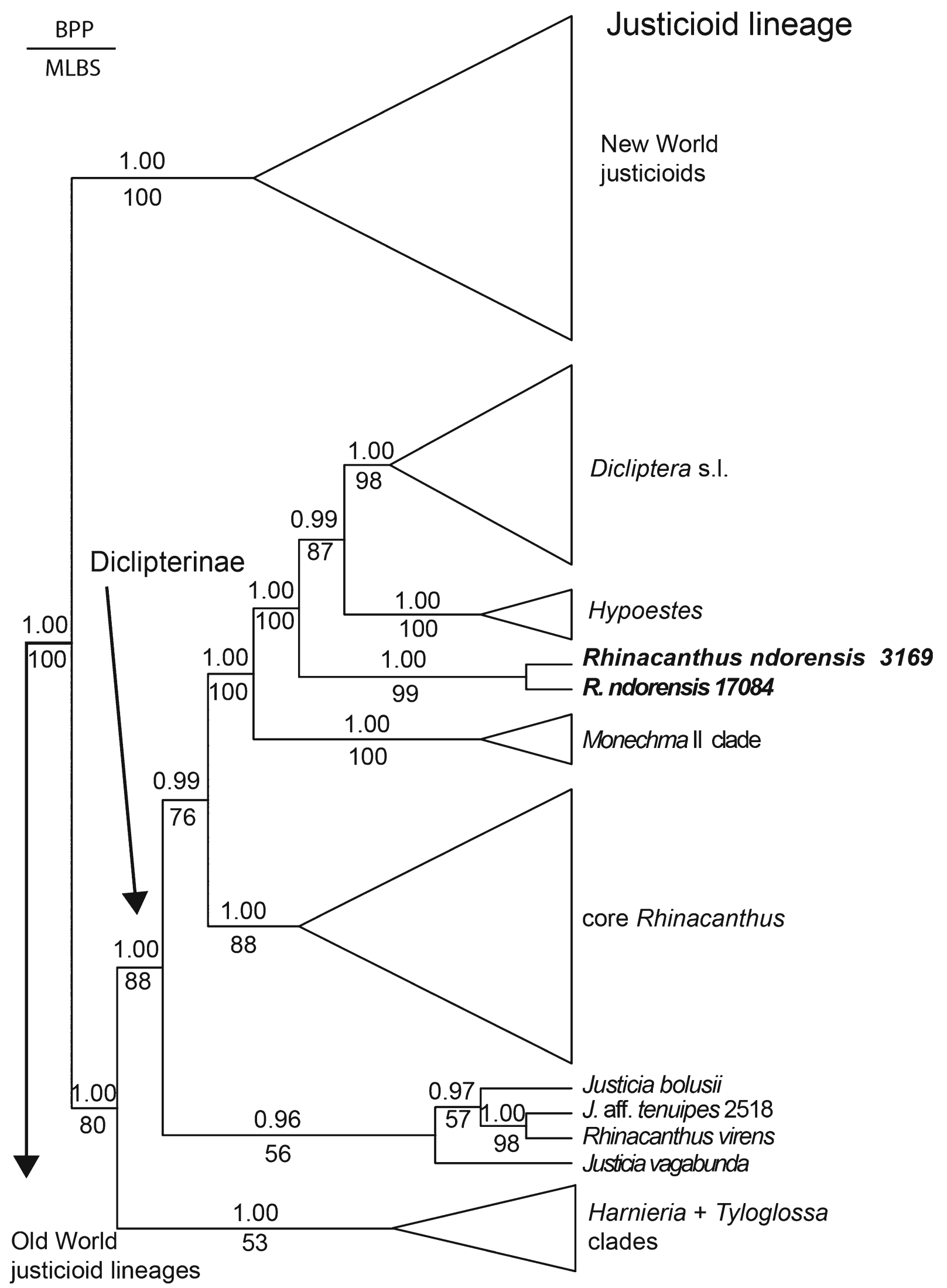

Fig. 2. Summary of phylogenetic relationships among Diclipterinae in the "justicioid" lineage highlighting Rhinacanthus ndorensis (= Kenyacanthus ndorensis) from Maximum likelihood. BPP = values above branch and MLBS= values below branch. 

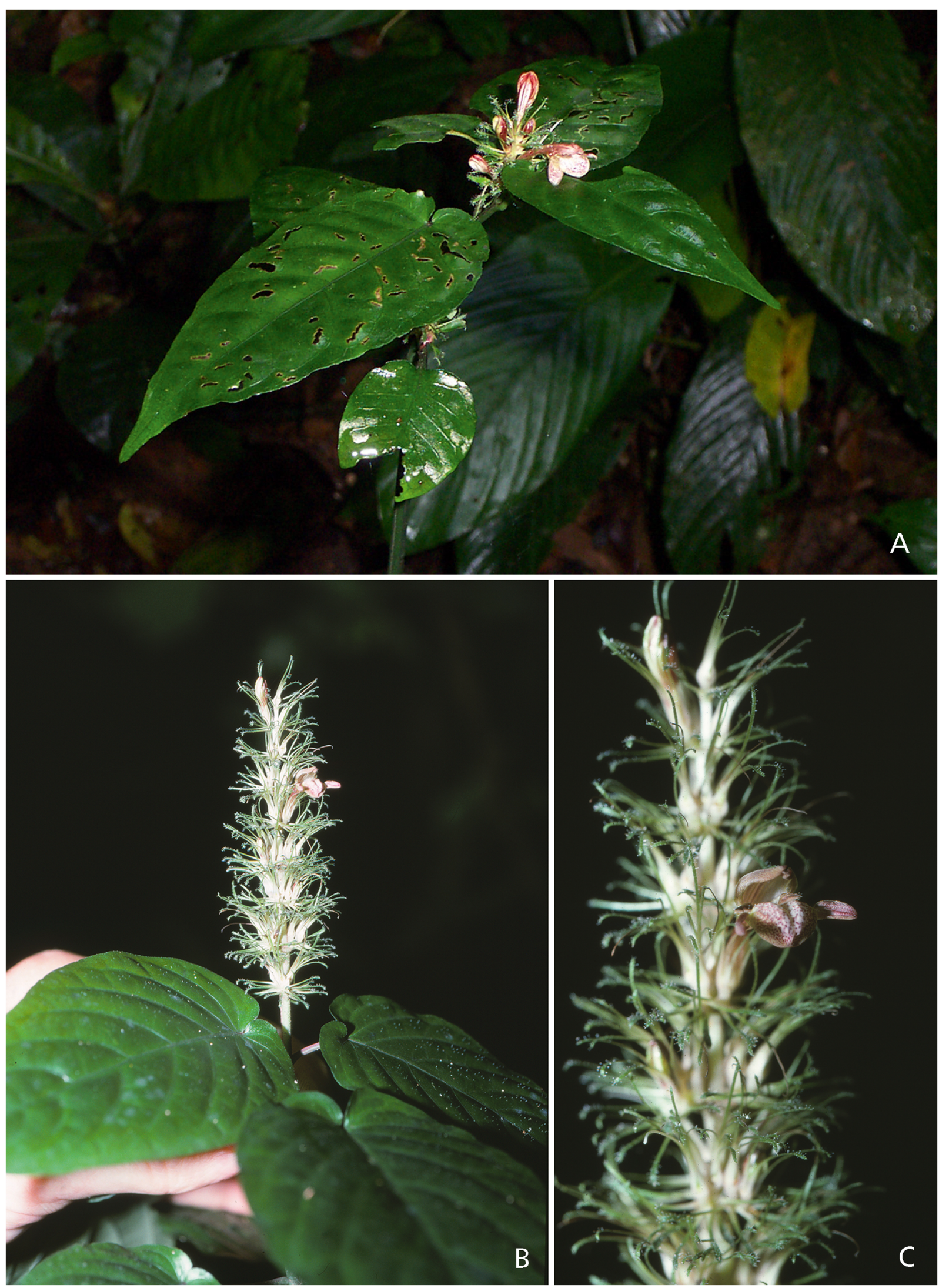

Fig. 3. Champluviera populifolia in the field, Cameroon. PHOTOS: A J. OSBORNE (collected as Osborne 97); B \& C M. CHEEK. 


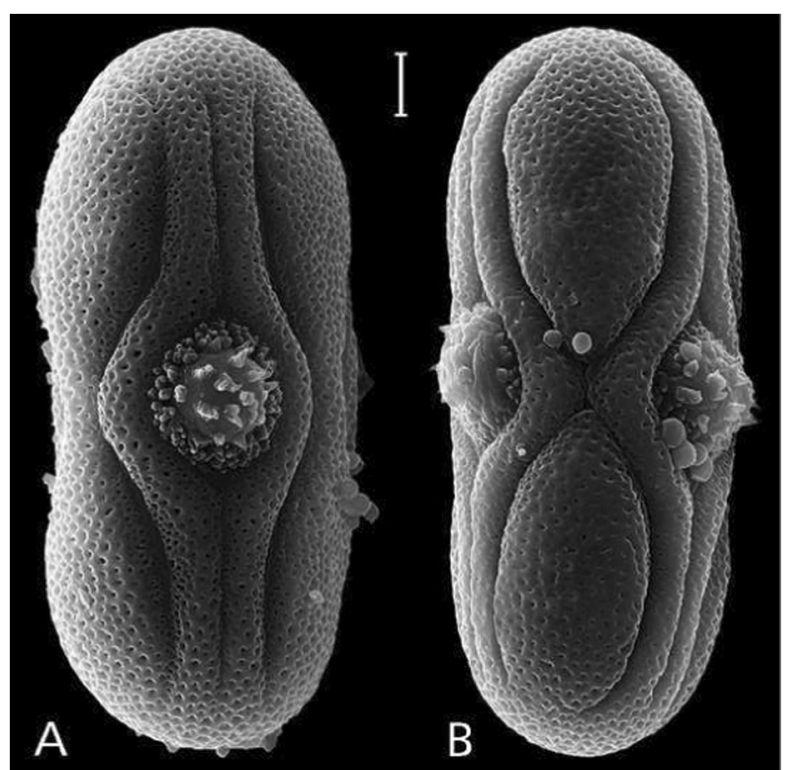

Fig. 4. Pollen of Champluviera populifolia. A equatorial view showing the compound aperture and pseudocolpi; B equatorial view showing the mesocolpium with equatorially fused pseudocolpi (from Cheek 7771).

to those of Justicia tigrina Heine from Gabon (D. Champluvier, pers. comm.). Justicia tigrina is based on Chlamydocardia nuda C.B.Clarke, a species that Clarke (1900b) had only tentatively placed in Chlamydocardia, noting that it lacked the characteristic bracts of that genus (see Darbyshire \& Govaerts 2017). Heine (1966) recorded the anther appendage of J. tigrina as resembling a chicken's crest ("en forme de crête de poule", p. 220) which is an apt description for the flattened broad appendage with an irregularly toothed fringe. He further noted that this appendage corresponds well to that of the other species of Justicia treated in the Flore du Gabon account, and it was on this basis that he transferred C. nuda to Justicia. In doing so, Heine, was obliged to give the species a new name, because the epithet "nuda" was already occupied in Justicia - J. nuda (Nees) O.Schwartz (1939: 259).

We concur with Dr Champluvier that, based on morphological evidence, Schaueria populifolia and Justicia tigrina are closely allied. They are vegetatively very similar, have a similar inflorescence type and the anther morphology is closely similar except that the thecae are more markedly offset in J. tigrina. However, neither the morphological nor the molecular evidence support the placement of these species within Justicia. Contrary to Heine's (1966) statement, the anther appendages differ significantly from African species of Justicia where often only the lower theca has an appendage (but note that appendages on both thecae is more frequent in New World Justicia - see, for example, Daniel 1995b; Kiel et al. 2017, Fig. 4E - F) and the appendage is usually longer than it is broad, often markedly so, and is untoothed except sometimes for a forked apex. This is in marked contrast to the broad, short and flattened appendage with an irregularly toothed fringe in $S$. populifolia and J. tigrina (Fig. 5). Furthermore, both of these latter species lack a rugula (stylar furrow), whilst species of Justicia have rugulate corollas (Kiel et al. 2017).

Unfortunately, suitable material for DNA analysis of Justicia tigrina was not available for the current study and so we have been unable to test the phylogenetic relationship between Schaueria populifolia and J. tigrina. However, as just described, the detailed morphological examination conducted in this study strongly supports the hypothesis that they are closely related.

Our results place Schaueria populifolia in a wellsupported clade of several genera that are together sister to the core Isoglossinae lineage, albeit without strong support (Fig. 1). This result is congruent with morphological evidence. Core Isoglossinae, a clade that includes the large genera Isoglossa Oerst. (OW) and Stenostephanus Nees (NW), is well-marked by structural synapomorphies: plants have gürtelpollen, i.e. biporate pollen that is circular in apertural view and with a broad marginal girdle (Kiel et al. 2006), although this can be modified to 3 (- 4)-porate pollen in Brachystephanus Nees (Figueiredo \& KeithLucas 1996; Champluvier \& Darbyshire 2009). In contrast, the clade of genera sister to Core Isoglossinae, including S. populifolia and Ptyssiglottis T.Anderson, have different pollen types (Kiel et al. 2006). This clade includes only one other African representative so far as is known at present, that being Monothecium Hochst. Monothecium comprises two species in continental Africa one of which extends to India; a third, Malagasy species (M. leucopterum Benoist) is unlikely to belong to Monothecium in view of several morphological differences (I. Darbyshire, pers. obs.). Monothecium is easily separated from S. populifolia and J. tigrina in, amongst other differences, having monothecous anthers lacking appendages (see Vollesen in Darbyshire et al. 2010).

The other genera allied to Schaueria populifolia are confined to Asia: Calycacanthus K.Schum., Jadunia Lindau, Marcania J.B.Imlay and Ptyssiglottis. Of these, only the last could potentially be confused with the African plants. Ptyssiglottis was most recently revised by Hansen (1992) who recognised 33 species, occurring from Sri Lanka eastwards through Southeast Asia to New Guinea. It differs from S. populifolia and Justicia tigrina in anther form and inflorescence characteristics. All species of Ptyssiglottis have nonappendaged anthers with the exception of P. mucronata B.Hansen from Sumatra, which has a sharply mucronate base to each theca (Hansen 1992). However, this is quite different to the broad, irregularly fringed appendages seen in S. populifolia and J. tigrina. In Ptyssiglottis, the inflorescence is 


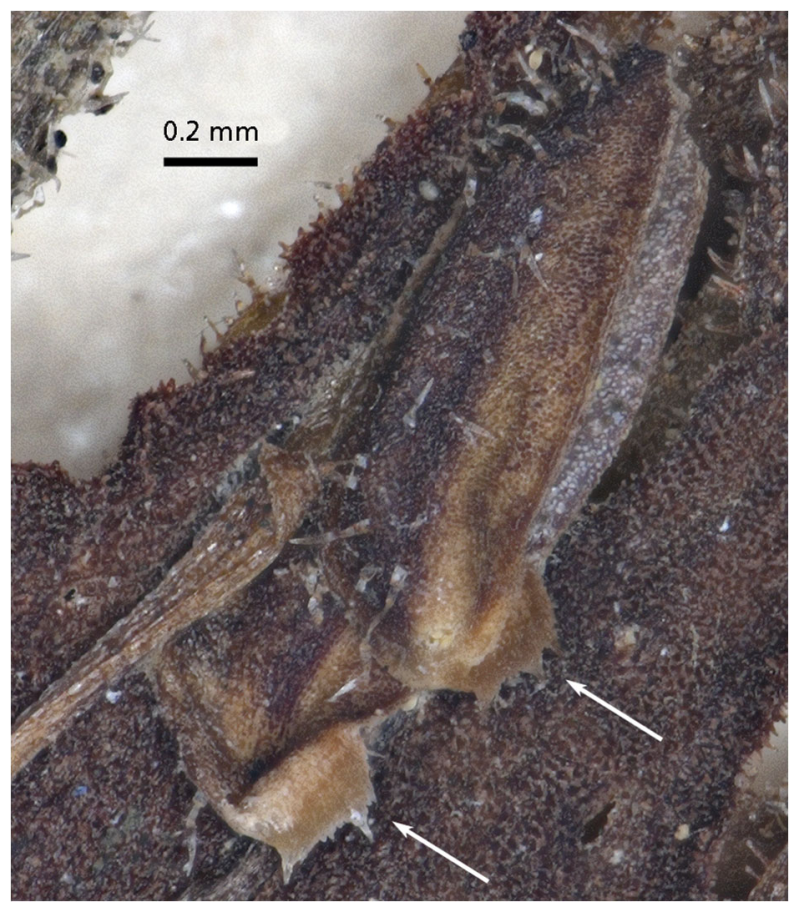

Fig. 5. Anthers of Champluviera nuda (from Bates 494, BM). PHOTO: HANNAH ARMER (NATURAL HISTORY MUSEUM, LONDON).

axillary and is a variation of a compound dichasium, usually branched dichotomously. In some species (e.g. P. pubisepala (Lindau) B.Hansen, sampled here), a lax compound dichasium with elongate internodes is fully developed, but in many species (e.g. P. psychotriifolia (Stapf) B.Hansen, sampled here) the dichasium is reduced and contracted, confined to two (to four) contracted branches, these often bearing several pairs of imbricate, scale-like bracts (Hansen 1992). In S. populifolia and J. tigrina, in contrast, the inflorescence is a terminal spiciform thyrse, with the dichasial cyme units arranged along a central, indeterminate axis. Pollen morphology is variable in Ptyssiglottis, but some pollen types are somewhat similar to that of $S$. populifolia, having the 3-colporate 6-pseudocolpate grains with enlarged ora, although the pseudocolpi are not or only slightly convergent in the mesocolpium (see Hansen 1992, Figs. 10 and particularly 11). Ptyssiglottis is not monophyletic in our results but, with only two species sampled, this result must be viewed as preliminary. Further sampling is warranted to investigate this further.

Based on the molecular and morphological evidence presented, our data indicate that a new genus is warranted to accommodate Schaueria populifolia within the lineage sister to Core Isoglossinae and we describe the new genus Champluviera I.Darbysh., T.F.Daniel \& C.A.Kiel below. Further, based on the close morphological similarity between $S$. populifolia and Justicia tigrina, we include the latter species within
Champluviera; this treatment should be tested in future via acquisition of material suitable for DNA analysis.

\section{Taxonomic Treatment}

Champluviera I. Darbysh., T.F.Daniel $\mathcal{E}$ C.A.Kiel genus nov. Type species: Champluviera populifolia (C.B.Clarke) I.Darbysh. \& T.F.Daniel

http://www.ipni.org/urn:lsid:ipni.org:names:77197847-1

Perennial herbs or subshrubs, erect or decumbent; young stems somewhat 4- or 6-angular. Leaves opposite-decussate, petiolate, pairs isophyllous, blade ovate or oblongovate to elliptic or oblong-elliptic; cystoliths present, linear, numerous, conspicuous in dry state at least on adaxial leaf surface. Inflorescences terminal, spiciform, comprising a series of opposite subsessile or shortly pedunculate cymes arranged along an indeterminate axis, i.e. a spiciform thyrse; bracts (excluding those pairs at base of inflorescence spike), bracteoles and calyx lobes subequal in size and shape, linear, linear-spathulate or linear-lanceolate; flowers subsessile or shortly pedicellate. Calyx divided almost to base into five lobes, subequal to somewhat unequal in length. Corolla intricately speckled and/or striped, rugula absent; aestivation ascendingcochlear, limb bilabiate; upper lip with apex shortly bilobed, lower lip 3-lobed. Stamens 2, inserted on interior of corolla tube, anthers exserted, dehiscing toward lower lip (i.e. flowers nototribic), bithecous, thecae parallel or slightly oblique, very slightly to more markedly offset, both thecae with a flattened, broad, irregularly toothed appendage at the base; staminodes absent. Floral disk annular, fleshy, $0.5-0.7 \mathrm{~mm}$ tall. Ovary oblong-ellipsoid, 4-ovulate; style filiform; stigma shortly bilobed. Capsule (where known) 4-seeded (or fewer by abortion), retinaculate, stipitate; seeds (only seen in immature state) tuberculate.

RECOGNITION. Champluviera is recognised by having the combination of a dense spiciform terminal thyrse with the bracts, bracteoles and calyx lobes all slender and closely resembling one another; a bilabiate corolla lacking a rugula and with intricate speckling or striping on the lips; and, in particular, anthers comprising two slightly to more markedly offset thecae each of which has a broad flattened basal appendage with an irregular fringe, and at least the upper theca having a line of trichomes on the exposed side. It differs from Schaueria primarily in having appendaged and pubescent anthers and in having speckled or striped corolla lips (vs anthers lacking appendages and glabrous, corollas not speckled or striped). It differs from Justicia primarily in the corolla lacking a rugula and in the anther appendages being broad and irregularly 
toothed (vs corolla with a rugula, anther appendages elongate to rounded and smooth except sometimes for a forked apex). Champluviera populifolia also has an apparently unique pollen type in which the two pseudocolpi of each mesocolpium converge towards the equator and sometimes meet, forming an hour-glass or figure eight shape. It is not clear, however, whether the second species, C. nuda, has the same pollen type (see Note to that species).

ETYMOLOGY. This genus is named in honour of $\mathrm{Dr}$ Dominique Champluvier (previously of the BR herbarium), an expert on the Acanthaceae of Africa with a particular interest in the Central African region. Dominique was the first to recognise the close relationship between the two species in this new genus.

\section{Key to species of Champluviera}

Corolla tube 10 - $14 \mathrm{~mm}$ long, clearly longer than limb, corolla glabrous externally except for few trichomes at apex of lower lip; anther thecae only very slightly offset; bracteoles and calyx lobes typically linear-spathulate with a blunt tip, usually with conspicuous glandular trichomes distally [Nigeria, Bioko, Cameroon] . . . . . . . C. populifolia

Corolla tube $6-8 \mathrm{~mm}$ long, only slightly longer than limb, corolla pubescent externally; anther thecae markedly offset; bracteoles and calyx lobes linear-lanceolate with a sharply acute tip, glandular trichomes minute and inconspicuous $[$ Gabon $] \ldots \ldots \ldots \ldots \ldots \ldots \ldots \ldots \ldots \ldots \ldots \ldots \ldots \ldots \ldots \ldots$. nuda

Champluviera populifolia (C.B.Clarke) I.Darbysh. $\mathcal{E}$ T.F.Daniel comb. nov.

http:/ /www.ipni.org/urn:lsid:ipni.org:names:77197848-1

Schaueria populifolia C.B.Clarke, Fl. Trop. Afr. 5: 242 (1900a); Hutchinson \& Dalziel (1931: 263); Heine (1963: 423); Lebrun \& Stork (1997: 503); Vollesen in Cable \& Cheek (1998: 5); Vollesen \& Darbyshire in Cheek et al. (2004: 230). Type: Equatorial Guinea, Fernando Po [Bioko], fl. 1862, Mann 1426 (K! [K000419169] lectotype, selected here). Additional syntypes: Equatorial Guinea, Bioko, in bud Nov. 1841, Vogel s.n. (K! [K000419170]); Cameroon, Bipinde, fl. 1896, Zenker 1205 (BM! [BM000949851], K!, M* [M0186812], S* [S095904], WAG* [WAG0248378]).

Justicia populifolia (C.B.Clarke) Champl. ined. sensu Onana (2011: 31; 2013: 64), nom. nud.

Perennial herb or subshrub, $30-200 \mathrm{~cm}$ tall, erect or decumbent, sometimes rooting at lower nodes; young stems somewhat 4- or 6-angular, furrowed in dry state, markedly swollen above each node (often shrunken in dry state), with two opposite-decussate lines of short retrorse trichomes most numerous below each node, trichomes multicellular with conspicuous dark cell walls, stems also with numerous minute red-brown sessile glands throughout; mature stems terete. Leaves with a strong liquorice odour (fide Bos 5548); petioles 18 - $66 \mathrm{~mm}$ long, furrowed above, antrorsepuberulous; blade dark green above, sometimes paler or purplish along main veins, pale grey-green to purplish beneath, ovate, oblong-ovate or ovate-elliptic, $6.2-19.7 \times 3.4-10.5 \mathrm{~cm}$ (length : width ratio $1.5-2.5$ : 1), base cordate, sometimes asymmetrically so, margin entire or obscurely undulate, apex acuminate, adaxial surface glabrous or with scattered short multicellular trichomes that appear deflated in dry state, abaxial surface antrorse-puberulous along main veins, margin with few short patent glandular trichomes in proximal half; cystoliths linear, numerous and conspicuous on adaxial surface, most dense along veins, both surfaces also with numerous minute redbrown sessile glands; lateral veins $6-9$ pairs, brochidodromous, prominent beneath, with \pm scalariform tertiary veins. Inflorescence a terminal spiciform thyrse with few flowers open at any one time, $(1.8-) 3.5-$ $11 \times 2-2.7 \mathrm{~cm}$, comprising a series of opposite (sub)sessile dichasia, these at first 3-flowered but can become manyflowered with age; rachis greenish-white or purplish, indumentum as that of stem but trichomes can be more dense; bracts along rachis greenish-white or purplish towards base, apical portion darker, linear, linearspathulate or more rarely linear-lanceolate, $6.5-14 \times 0.3$ - $1.3 \mathrm{~mm}$, pairs divergent, distal portion often ascending, apex usually obtuse or rounded, surface with short antrorse eglandular trichomes and with few to numerous spreading glandular trichomes distally, cystoliths numerous and conspicuous in proximal half or two thirds; bract pair at base of thyrse often somewhat larger, lanceolate, up to $4 \mathrm{~mm}$ wide; bracteoles as bracts but usually linearspathulate, $7.5-11.5 \times 0.3-0.8 \mathrm{~mm}$, apex sometimes slightly recurved; flowers subsessile or on stout glabrous pedicels to $2 \mathrm{~mm}$ long. Calyx lobes linear or usually linearspathulate, closely resembling the bracteoles, somewhat unequal in length, $8-12.5 \times 0.2-0.5 \mathrm{~mm}$, apex blunt, often slightly recurved, indumentum like that of bracts. Corolla 16 - $21 \mathrm{~mm}$ long, dull red, red-brown or purple, lower lip white to pale yellow with red to purple speckling; tube 10 - $14 \mathrm{~mm}$ long, basal cylindrical portion 7.5 $10 \mathrm{~mm}$ long, c. $1.2-1.7 \mathrm{~mm}$ in diam. at midpoint, expanded throat $3-4.5 \mathrm{~mm}$ long, glabrous externally, minutely puberulous within with mixed eglandular and 
glandular trichomes particularly on roof, with a diffuse broad band of longer eglandular trichomes starting 2.5 $4.7 \mathrm{~mm}$ from base, only sparsely hairy below this; upper lip triangular, $4.5-7.3 \times 4-5 \mathrm{~mm}$ when flattened but margins narrowly involute, apex shortly bilobed, lobes $0.5-$ $1.3 \mathrm{~mm}$ long, tips reflexed; lower lip $4.5-7 \mathrm{~mm}$ long, deeply 3-lobed, lateral lobes lanceolate, $2.3-4.2 \times$ $1-2.2 \mathrm{~mm}$ when flattened, median lobe broadly rounded, $1.8-3 \times 3-3.6 \mathrm{~mm}$, with two raised, convergent ridges and a central furrow and with prominent reticulate venation, lips glabrous externally except for few short trichomes at apices of lower lobes. Stamens inserted $6.3-8.7 \mathrm{~mm}$ from base of corolla; filaments free for $5-7.5 \mathrm{~mm}$, flattened either side of raised central vein, shortly pubescent at base and along fused portion, glabrous distally; anthers bithecous, thecae parallel or slightly oblique, slightly offset by c. $0.15 \mathrm{~mm}$, narrowly oblong, $1.9-2.4 \mathrm{~mm}$ long, both with broad subsessile glands on adhering surfaces, upper (inner) theca with dense band of short multicellular eglandular trichomes and shorter capitate glandular trichomes dorsally along exposed side, lower (outer) theca glabrous on exposed side, both thecae with broad flattened, slightly protruding appendage below suture with irregular fringe of conical teeth to $0.07 \mathrm{~mm}$ long. Pollen perprolate, 3-colporate, 6-pseudocolpate, polar diameter (P) $57-60 \mu \mathrm{m}$, equatorial diameter (E) $24 \mu \mathrm{m}, \mathrm{P}: \mathrm{E}=2.37-$ 2.5 , ora considerably wider than colpi and with membrane echinate (to gemmate), the two pseudocolpi in each mesocolpium curved toward one another equatorially (and sometimes toward poles as well) and sometimes fusing at equator forming an hour-glass or figure eight shape, interaperatural exine reticulate. Floral disk annular, fleshy, 0.5 - $0.7 \mathrm{~mm}$ tall. Ovary black, oblong-ellipsoid, 1.1 $1.6 \mathrm{~mm}$ long, glabrous; style pale orange-brown in dry state, $10-13.5 \mathrm{~mm}$ long, with few pale eglandular trichomes at base; stigma shortly bilobed. Capsule c. $17.5 \mathrm{~mm}$ long including stipe $8 \mathrm{~mm}$ long, apex shortly attenuate, surface glabrous; immature seeds only seen, flattened, tuberculate. Figs 3, 4 and 6.

DISTRIBUTION. Nigeria (Cross River State), Equatorial Guinea (Bioko), Cameroon (Southwest, Littoral and South Regions); Map 1.

SPECIMENS EXAMINED. NIGERIA. Cross River State: Oban Distr., fl. 1911 - 1912, Talbot s.n. (K!); Oban, fl. 1911, Talbot 993 (BM, K!); Ogoja Prov., Ikom Distr., Cross River North Forest Reserve, fl. 7 Dec. 1950, Keay in FHI 28157 (FHI, K!); Ogoja Prov., Ikom Distr., Afi River Forest Reserve, fl. 13 Dec. 1950, Keay in FHI 28238 (FHI, K!). EQUATORIAL GUINEA. Bioko (unplaced): Fernando Po [Bioko], fl. 1862, Mann 1426 (K! lectotype). Bioko Norte: Fernando Po [Bioko], Clarence Peak [Pico Basilé], in bud Nov. 1841, Vogel s.n. (K!). CAMEROON. Southwest Region: Meme Div., Southern Bakundu Forest Reserve, near Pete, 28 Nov. 1985, Thomas $\mathcal{E}^{\circ}$ Nemba 5022 (MO!); Ndian Div., along path from "Fabe Road” towards Fabe, fl. 22 Nov. 1986, Manning 916 (K!,
MO!); Korup N.P., WCI study area, $35 \mathrm{~km}$ W of Nguti, fl. 18 Jan. 1991, Harris 2704 (K!); Mabeta-Moliwe, Diculu, fl. 16 Dec. 1993, Cable 585 (K!, SCA, YA); Ndian Div., N of Mundemba at second crossing of Moliba R. on Ekundu Kundu road, fl. 12 Dec. 1994, Gereau et al. 5666 (K!, MO!); Mt Kupe SW slope, main trail leading to the summit, fl. 11 July 1995, Ensermu 3533 (K!, YA); Mt Kupe, path to Kupe rock along Esense R., fl. 2 Nov. 1995, Cheek 7654 (BR*, K!, MO!, P, SCA, WAG, YA); Mt Kupe, SW slope, Muanenzum trail, fl. 6 Nov. 1995, Schoenenberger 26 (K!, YA); Mt Kupe, main trail to the top from Kupe village, fl. 13 Nov. 1995, Schoenenberger 53 (K!, YA); Mt Kupe, path to top of Kupe rock, fl. 14 Nov. 1995, Cheek 7771 (BR*, K!, MO!, NY, P*, SCA, US, WAG, YA); Meme Div., Mungo River Forest Reserve, $\mathrm{S}$ of Kumba-Tombel road, c. $1 \mathrm{~km}$ from Mungo bridge, fl. \& fr. 26 Nov. 1999, Cheek 10153 (K!, SCA, YA); Ngomboku, on path to Mbombe hill, fl. 9 Dec. 1999, Mackinder 292 (BR*, K!, SCA, YA); Banyang-mbo Sanctuary, Research Station path to sanctuary via Nlowoa and Mbu river crossings, fl. 25 Nov. 2000, Cheek 10605 (K!, MO, WAG, YA); Mone Forest Reserve, Mokoyong to Tafu path, 2.5 hrs E, 30 Nov. 2000, Cheek 13984 (K!). Littoral Region: Forêt de Bakaka, $3 \mathrm{~km}$ E of Eboné (km 11 Nkongsamba-Loum road), fl. 17 Dec. 1971, Leeuwenberg 8913 (K!, WAG); près Yingui II, à 5 km à l'ENE de Yingui, $35 \mathrm{~km}$ E de Yabassi, fl. \& fr. 8 Jan. 1972, Letouzey 10919 (K!, P*); Ebo Proposed N. P., Bekob, fl. 15 Feb. 2006, Tchiengue 2486, (K! YA); Ebo Proposed N. P., Ebo Forest Research Station, W transect, fl. 9 Oct. 2006, Osborne 97 (K!, WAG, YA); Ebo Proposed N. P., Ebo Bekob forest, fl. 26 Nov. 2013, Tchiengue 3613 (K!, MO, P*, WAG, YA); Ebo Proposed N. P., Bekob camp, fl. 2 Dec. 2013, Ngansop 187 (K!, WAG, YA). South Region: Bipinde, fl. 1896, Zenker 1205 (BM!, K!, M*, P*, S*, WAG*); au $\mathrm{S}$ de Zingui, $40 \mathrm{~km}$ ESE de Kribi, fl. 20 Jan. 1962, Letouzey 4072 (K!, P*); Mviglimangalé, $16 \mathrm{~km}$ E Nayabesan, $1 \mathrm{~km}$ NW village, fl. 15 Feb. 1965, Raynal 13411 ( $\left.\mathrm{P}^{*}\right)$; près de R. Kienke, au NNW de Nkolbewa, km 35 route Kribi-Ebolowa, fl. 12 March 1968, Letouzey 9001 (K!, YA); about $11 \mathrm{~km}$ from Kribi, between airfield and Kienke, fl. 27 Oct. 1969, Bos 5548 (BR*, WAG); c. 5 km SSE of Bipindi, fl. \& fr. 14 Jan. 1987, Manning 1336 (K!, MO!, YA*); Efoulan, au sud d'Akom II (mi-chemin entre Ebolowa et Kribi), fl. 11 May 2009, Lachenaud et al. $737\left(\mathrm{BR}^{*}\right)$.

HABITAT \& ECOLOGY. This species is recorded from 1lowland rainforest in deep shade, sometimes being recorded from swamp and riverine forests. It can also persist in secondary and disturbed forest patches; 70 $900 \mathrm{~m}$ elevation.

PHENOLOGY. Champluviera populifolia has been recorded in flower most frequently in the months of 


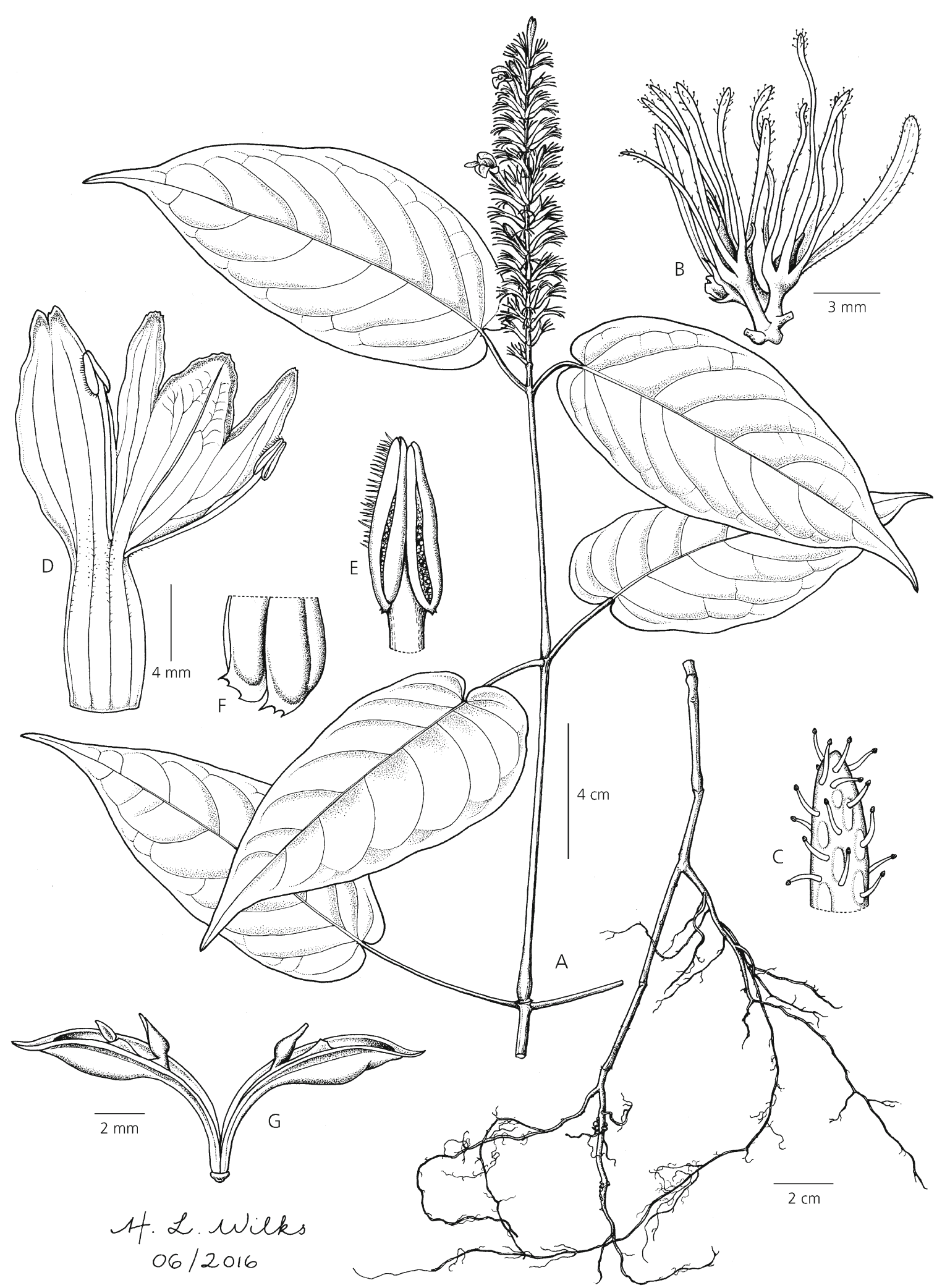

Fig. 6. Champluviera populifolia. A habit: rootstock and distal portion of flowering stem; B dichasial inflorescence unit showing calyces and bracteoles (some bracteoles cut away at base); C apex of calyx lobe showing glandular trichomes; D dissected corolla with androecium; $\mathrm{E}$ anther; $\mathrm{F}$ detail of anther base showing thecal appendages; G dehisced capsule. A from Ngansop 187 with rootstock from Osborne 97, B from Cheek 10153; C - E from Ngansop 187; F from Gereau et al. 5666; G from Manning 1336 and Cheek 10153. DRAWN BY HAZEL WILKS. 


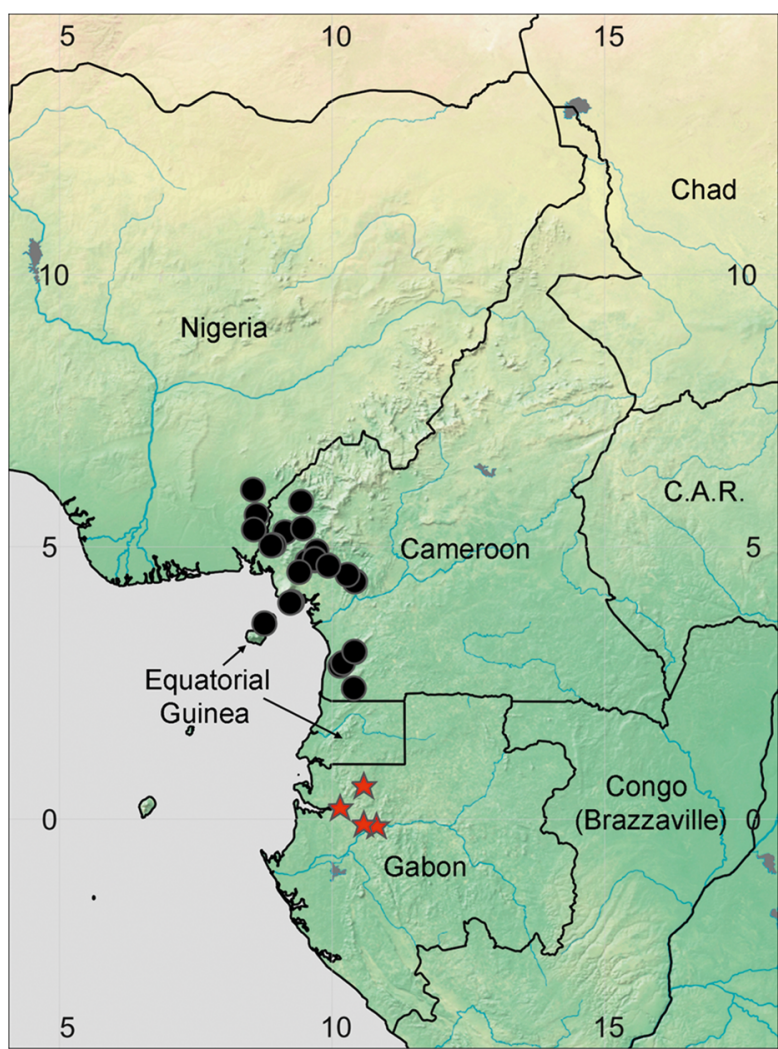

Map 1. Distribution of Champluviera: C. populifolia (black circles), C. nuda (red stars).

(October -) November - December (- January) but with occasional records from February, March, May and July. The peak flowering time coincides with the onset of the dry season within this species' range.

CONSERVATION STATUS. This species was recorded as Near Threatened (NT) by Vollesen \& Darbyshire (in Cheek et al. 2004). It appears to be fairly frequent in the lowland to mid-altitude forests of the Cameroon Highlands and southwestern Cameroon but its favoured habitat is threatened through large parts of its range due to timber extraction and forest clearance for subsistence and commercial agriculture. It has an EOO of $53,797 \mathrm{~km}^{2}$ which is considerably greater than the $20,000 \mathrm{~km}^{2}$ threshold for Vulnerable under IUCN criterion $\mathrm{B} 1$ and has up to 20 locations historically but some of these are likely to have been lost. The assessment of Near Threatened (NT) under criterion $\mathrm{B}$ is therefore upheld here.

NOTES. Mann 1462 (K) is chosen as the lectotype, as it is the most informative of the three syntypes and, from his annotations and illustrations on this specimen, it is clear that Clarke (1900a) used it as the basis for his description in the protologue.

Champluviera nuda (C.B.Clarke) I.Darbysh. E T.F.Daniel comb. nov. http:/ /www.ipni.org/urn:lsid:ipni.org:names:60478962-2

Chlamydocardia nuda C.B.Clarke, Fl. Trop. Afr. 5: 235 (1900b); Darbyshire \& Govaerts (2017: 4). Type: Gabon, Mabam, Como R., 60 miles from Gaboon, fl. 13 July 1896, Bates 494 (K! [K000419168] holotype; BM! [BM000931152], L* [L0003054], P! [P00540805] isotypes).

Justicia tigrina Heine, Fl. Gabon 13: 219, pl. XXXVIII 10 - 13 (1966); Lebrun \& Stork (1997: 489); Sosef (2006: 38). Type as for Chlamydocardia nuda.

Perennial herb or subshrub, $70-180 \mathrm{~cm}$ tall, basal stems trailing and rooting at nodes, decumbent; young stems somewhat 6-angular, \pm evenly pubescent with sparse antrorse to appressed eglandular trichomes and with opposite lines of denser trichomes, older internodes glabrescent. Leaves petiolate, petioles to $70 \mathrm{~mm}$ long, furrowed above, antrorse-puberulous; blade \pm concolorous, green or dark glaucous-green, elliptic, oblong-elliptic or ovate-elliptic, $8.5-15.5 \times 3.6-8 \mathrm{~cm}$ (length : width ratio $(1.75-) 2.1-2.8: 1$ ), base rounded, shallowly cordate or obtuse, can be somewhat asymmetric, margin entire or irregularly undulate, apex acuminate, surfaces sparsely pubescent on main veins, with antrorse eglandular trichomes; cystoliths linear, numerous and conspicuous on both surfaces when dry, surfaces also with numerous minute red-brown sessile glands; lateral veins $6-8$ pairs, brochidodromous, pale and prominent beneath Inflorescence a slender erect terminal spike to 15 $24.5 \mathrm{~cm}$ long including peduncle to $0.5-1.2(-3) \mathrm{cm}$ long, comprising a series of opposite $1-3$ (potentially more)-flowered cymes, those at base of spikes borne on peduncles to $2.5 \mathrm{~mm}$ long, those in distal portion of spike sessile or peduncle to $0.5 \mathrm{~mm}$; rachis \pm evenly pubescent with antrorse eglandular trichomes like those of young stems; bracts opposite, green, linearlanceolate, $6-8 \mathrm{~mm} \times$ c. $1 \mathrm{~mm}$, pubescent abaxially, like rachis; bracteoles similar to bracts in shape and size but can have a more puberulent indumentum and can be purplish (drying brown); pedicels to $1.5(-2.5)$ $\mathrm{mm}$ long, puberulent. Calyx purple or grey-purple in live state at least towards base and apex, drying brown, divided almost to base into five subequal to \pm unequal linear-lanceolate lobes resembling the bracteoles, 7.5 $11 \mathrm{~mm}$ long, puberulent externally with mixed erect glandular and eglandular trichomes to $0.05 \mathrm{~mm}$ long. Corolla $\pm 11-14 \mathrm{~mm}$ long, yellow with dark purple stripes on upper lip and dark purple speckling on lower lip, pubescent externally with erect eglandular trichomes; tube $\pm 6-8 \mathrm{~mm}$ long, cylindrical; limb bilabiate with lips $\pm 5.5-6 \mathrm{~mm}$; upper lip hooded, apex shortly bilobed; lower lip pendant, shortly 3lobed. Stamens 2; filaments $\pm 4 \mathrm{~mm}$ long (fide Heine 1966), glabrous; anthers with thecae unequally 
inserted, overlapping by $0.8-0.9 \mathrm{~mm}$, thecae narrowly elliptic, $1.3-1.6 \mathrm{~mm}$ long, with multicellular eglandular trichomes along the exposed side more numerous on upper theca, and both with a flattened, broad appendage at base below suture with irregularly toothed fringe. Pollen not seen (see note). Floral disk annular, $\pm 0.5 \mathrm{~mm}$ tall. Ovary $\pm 2 \mathrm{~mm}$ long, glabrous; style $\pm 11 \mathrm{~mm}$ long (fide Heine 1966), with eglandular trichomes towards base; stigma shortly bilobed. Capsule not seen. Fig. 5 .

DISTRIBUTION. Gabon (Estuaire, Moyen-Ogooué and Woleu-Ntem Provinces); Map 1.

SPECIMENS EXAMINED. GABON. Estuaire Province: Mabam, Como R., 60 miles from Gaboon, fl. 13 July 1896, Bates 494 (K! holotype; BM!, L*, P! isotypes); Abanga Chantier C.E.T.A., fl. 3 June 1963, N. Hallé 2176 (P! [P03616770, P03616771]); idem, fl. 8 June 1963, N. Hallé 2362 (P! [P03616769]). MoyenOgooué Province: $15 \mathrm{~km}$ NE of Ndjolé, Exploitation road, 31 Jan. 1991, de Wilde Eं Sosef 10329 (WAG [WAG0130200], n.v.). Woleu-Ntem Province: Crystal Mts, Tchimbélé, fl. 23 Jan. 2001, Mayombo-Nzengue 271 (LBV* [LBV0019437]).

HABITAT \& ECOLOGY. This species is recorded from primary wet forest, shaded river margins and in alluvial silts by streams; the elevation range is estimated at $10-630 \mathrm{~m}$.

PHENOLOGY. Phenology information on this species is very limited; three of the four flowering specimens seen by the current authors were collected in June or July, during the short dry season; the fourth was collected in January during the wet season.

CONSERVATION STATUS. This species is clearly scarce, being known with certainty from only four herbarium collections, despite Gabon being one of the best explored countries botanically in Africa according to Sosef et al. (2017). It appears to have a highly restricted range with an EOO of $2890 \mathrm{~km}^{2}$ based on current knowledge. Of the four known localities, Ndjolé is an area of gold and manganese mining (https://mining-atlas.com/project/ Ndjole-Mangenese-Gold-Mine-Project.php) and the footprint of this mining activity along the Ogooué River is clearly visible on Google Earth ${ }^{\mathrm{TM}}$ imagery (accessed $15^{\text {th }}$ August 2018). This is likely to have impacted upon habitat suitable for this species. There is still extensive intact forest habitat elsewhere within its range, and this species is likely to occur at other localities within this small range. However, based on current knowledge, with an EOO of less than $5000 \mathrm{~km}^{2}$, fewer than five locations and an inferred decline in extent and quality of habitat due to mining activities, this species is provisionally assessed as Endangered - EN Blab(iii).

NOTES. This species is well illustrated in Heine (1966: pl. XXXVIII $10-13$ ). The anthers are illustrated in Fig. 5 here.
Sosef (2006) also lists Mayombo-Nzengue 390 (LBV) under this species but this collection number is listed as a Zingiberaceae in the LBV database and only Mayombo-Nzengue 271 is housed under Justicia tigrina at LBV (P. Bissiengou, pers. comm.). Further, Sosef et al. (1.c.) list Arends 570 (WAG) as Justicia cf. tigrina but this specimen was redetermined by $\mathrm{D}$. Champluvier as J. tristis T.Anderson, and we concur with this identification.

We have not seen the pollen of this species. Clarke (1900b) recorded the pollen as "globose with 12 equidistant ribs not reaching the pores" (p. 235) and illustrated it as such on a sheet of paper attached to the holotype specimen. He thought that there were 6 equidistant pores on the grains which supported the placement of this species in Chlamydocardia (see Darbyshire \& Govaerts 2017), but this does not seem to fit with the presence of 12 'ribs.' If the grains are colporate and pseudocolpate, then 12 ribs would suggest four germinal apertures — if Clarke (1900b) was correct then these grains are quite different to those of C. populifolia described above.

Heine (1966) notes the presence of "sterile floral buds" in this species - these are presumably cleistogamous flowers, which are not uncommon in some genera of Acanthaceae, for example in Isoglossa (Darbyshire et al. 2012).

Asystasia lindauiana Hutchinson \& Dalziel (1931: 257) could potentially be confused with Champluviera on morphological grounds and has a sympatric distribution, hence is worthy of mention here. The two are superficially very similar both in vegetative characters and inflorescence form, sharing a terminal many-flowered spiciform thyrse. Indeed, Clarke (1900b) remarked on this close superficial similarity when describing Chlamydocardia nuda. However, A. lindauiana is easily separated from Champluviera in having four stamens (a character shared by all species of Asystasia), and in the anthers having thecae markedly offset and lacking basal appendages. Molecular evidence confirms that these genera are not closely related, with Asystasia falling within the "Pseuderanthemum lineage" of Justicieae (McDade et al. 2000).

\section{Kenyacanthus - a new monotypic genus endemic to Kenya}

Notable morphological differences exist between Rhinacanthus ndorensis and species of Rhinacanthus s.s. In particular, $R$. ndorensis is unique in Rhinacanthus in the positioning of stamens, these being held against the lower lip of the corolla with thecae dehiscing towards the upper lip (i.e. flowers are stenotribic; Kiel et al. 2017). In Rhinacanthus s.s., the stamens are held between the two lips and dehisce toward the lower lip 
(i.e. flowers are nototribic). The two lips of the corolla in $R$. ndorensis are subequal in size, whilst in other Rhinacanthus the upper lip is markedly smaller and usually much narrower than the lower lip (Darbyshire \& Harris 2006; Darbyshire et al. 2018). In addition, as noted in the Introduction, $R$. ndorensis can be separated by its procumbent or trailing habit, fasciculate inflorescences, hyaline margins to the bracts, bracteoles and calyx lobes and essentially glabrous capsules. In other species of Rhinacanthus, plants are erect, decumbent or straggling, the inflorescences are usually lax panicles or spikes (although fascicled in $R$. rotundifolius C.B.Clarke), the bracts, bracteoles and calyces lack hyaline margins and the capsules are variously puberulous to pubescent with eglandular and/or glandular trichomes (Darbyshire \& Harris 2006). These morphological differences support the findings of the molecular analysis (Fig. 2) that $R$. ndorensis is not closely related to Rhinacanthus s.s.

Rhinacanthus ndorensis has 3-colporate, 6pseudocolpate pollen (Fig. 7), a pollen type that is hypothesised to be synapomorphic for Justicieae as a whole (Kiel et al. 2017) and that thus does not contribute to assessing the phylogenetic position of $R$. ndorensis within Justicieae.

The placement of Rhinacanthus ndorensis sister to core Diclipterinae, as confirmed in our analysis here (Fig. 2), is not surprising on morphological grounds, as this species could easily be confused with a member of the genus Dicliptera. Indeed, the general corolla morphology, with the lips being widely divergent and subequal in size, is very similar to that of African Dicliptera. Inflorescences of Dicliptera are typically of monochasial units (cymules) with conspicuous paired clasping bracts that are often umbellately arranged (Balkwill et al. 1996; Darbyshire 2009). However, some species have solitary or fascicled axillary inflorescences

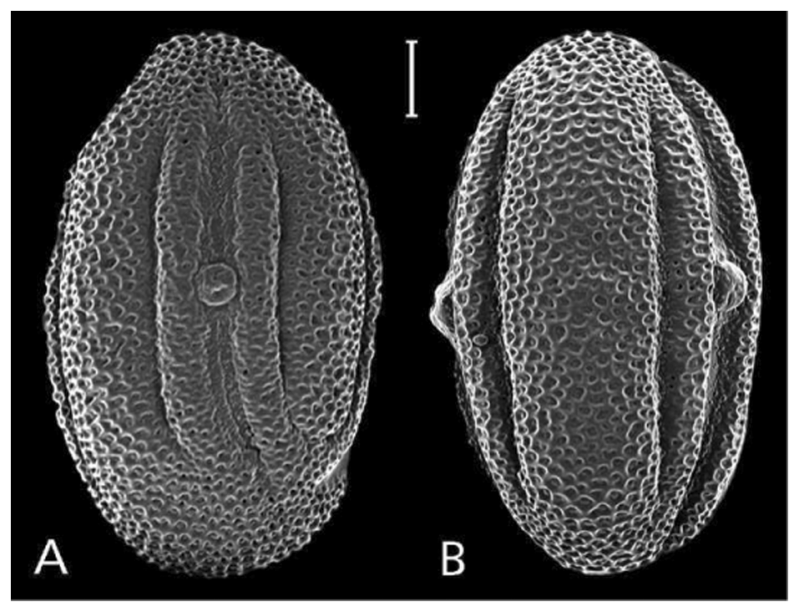

Fig. 7. Pollen of Kenyacanthus ndorensis. A equatorial view showing the compound aperture and pseudocolpi; B equatorial view showing the mesocolpium (from Luke 17084). with reduced cymule bracts (e.g. D. minutifolia Ensermu from Ethiopia and Kenya; Ensermu 2003; Darbyshire et al. 2010) which are similar to the inflorescences of $R$. ndorensis. Furthermore, hyaline margins on the bracts, bracteoles and calyces are fairly widespread in Dicliptera (see, for example, Balkwill et al. 1996; Darbyshire et al. 2010). However, $R$. ndorensis differs significantly from Dicliptera in floral morphology. In $R$. ndorensis the corolla tube is straight, not twisted, and, as noted above, the flowers are stenotribic with the stamens held against the lower, 3lobed lip of the corolla (Fig. 8). All OW species and many NW species of Dicliptera (and all species in the related genus Hypoestes) have a resupinate corolla, in which the tube is twisted through $\pm 180^{\circ}$, thus the 3lobed "lower" lip is held in the upper position, although Daniel \& Figueiredo (2009) note that in "D. verticillata (Forssk.) C.Chr." (possibly = D. hyalina Nees) from São Tomé the tube can be twisted by only $90^{\circ}$ such that the limb is held on its side. In these resupinate-flowered species, the flowers are effectively stenotribic. However, the positionally lower 2-lobed lip that the stamens are held against is actually the upper lip morphologically. In his synopsis of the species of Dicliptera in the Nueva Galicia region of western Mexico, Daniel (2009) noted three distinct floral forms: tube twisted through $180^{\circ}$, tube twisted through $360^{\circ}$ and tube untwisted. The latter two cases both result in non-resupinate corollas in which the 3-lobed lip is in the "normal" lower position. In these nonresupinate forms, the flowers are nototribic with the stamens held close to the upper corolla lip, quite different to those of $R$. ndorensis. The species of Dicliptera with non-resupinate flowers in the NW have large, brightly coloured and unspeckled red, orangeyellow or purple corollas that appear to be adapted for bird pollination (Daniel 2009; Kiel et al. 2017). These are quite unlike the small, pink flowers of $R$. ndorensis. The stamens of Dicliptera are usually exserted well beyond the corolla mouth and not appressed to the corolla lip as in $R$. ndorensis. Further, $R$. ndorensis differs from all African members of Dicliptera in having only slightly offset as opposed to fully superposed anther thecae. This character is, however, more variable in some species of NW Dicliptera (Kiel et al. 2017).

Rhinacanthus ndorensis is further separated from most taxa in core Diclipterinae by the presence of a rugula (stylar furrow), which in $R$. ndorensis comprises two raised ciliate bands of tissue running dorsally along the corolla tube and base of the upper lip (Fig. 9F), similar to the rugula seen in Rhinacanthus s.s. Whilst rugulas are widespread in the justicioid lineage, they are mainly lacking or indistinct in the core Diclipterinae lineage including Dicliptera (Balkwill \& Welman 2000; Darbyshire \& Vollesen 2007). The rugula is hypothesised to hold the style in position during anthesis, and it has been suggested that the loss 
of the rugula in core Diclipterinae occurred as a correlate of corolla resupination (Kiel et al. 2017), where the twisting of the corolla tube may hold the style in position. That said, recent observations on putatively bird-pollinated species of Hypoestes from Madagascar with elongate, expanded corolla tubes such as $H$. isalaensis Benoist have revealed the presence of a shallow rugula of two raised, ciliate lines not dissimilar to the rugula in $R$. ndorensis (I. Darbyshire, pers. obs.). It may be that this character is more widespread in taxa of Diclipterinae with enlarged corolla tubes.

Monechma Group II is sister to (Rhinanthus ndorensis (Hypoestes + Dicliptera s.l.)) (Fig. 2); the former is one of two widely separated clades comprising the nonmonophyletic genus Monechma Hochst. (= Justicia L. sect. Monechma (Hochst.) T.Anderson). However, $R$. ndorensis is unlikely to be confused morphologically with species of Monechma Group II as these plants have broader cylindrical corolla tubes, usually subequal in length to the limb, a markedly hooded upper corolla lip, stamens with a conspicuous appendage on the lower anther theca, capsules with two seeds and the seeds having a smooth testa. Rhinacanthus ndorensis, on the other hand, has a narrowly cylindrical tube clearly longer than the limb, the upper corolla lip is not hooded, the stamens lack appendages, the capsule is 4-seeded and the seeds are sculptured (Fig. 9J).

In summary, phylogenetically, Rhinacanthus ndorensis forms an isolated clade composed of, so far as known, a single species that is placed between (Hypoestes + Dicliptera s.l.) and the Monechma Group II (Fig. 2). Regarding morphological traits, R. ndorensis appears to be intermediate between plants belonging to the core Diclipterinae and those of the other clades that are part of the expanded Diclipterinae as recognised by Kiel et al. (2017), as described above (Figs 8 and 9). Thus, morphology and phylogenetic relationships based on DNA data are congruent.

Kiel et al. (2017) reviewed the potential taxonomic implications of their findings on the complex relationships within the "justicioid" lineage, and five potential solutions were offered. They noted that in order to maintain a broadly circumscribed Justicia as is currently widely accepted (see, for example, Graham 1988; Vollesen in Darbyshire et al. 2010), the entire "justicioid" lineage would potentially have to be treated as a single genus. This is highly undesirable as it would mean subsuming several genera that are easily separated by morphological differences, including those within Diclipterinae. The most credible solution offered therefore appears to be to divide Justicia s.l. into a number of segregate genera and to uphold the morphologically distinct genera such as Dicliptera, Hypoestes and Rhinacanthus s.s. Whilst the taxon sampling in Kiel et al. (2017) was insufficiently dense to support full revision of generic delimitations among justicioids, the strong morphological and molecular evidence presented here supports the recognition of a new genus to accommodate $R$. ndorensis, allied to but clearly separated from Dicliptera, Monechma and Rhinacanthus. In consequence, the new genus Kenyacanthus I.Darbysh \& C.A.Kiel is described below.

\section{Taxonomic Treatment}

Kenyacanthus I.Darbysh. E C.A.Kiel genus nov. Type species: Kenyacanthus ndorensis (Schweinf.) I.Darbysh. \& C.A.Kiel.

http://www.ipni.org/urn:lsid:ipni.org:names:77197855-1

Perennial herbs, with trailing or procumbent branches radiating from a small woody base; stems markedly angular with 2 opposite pairs of ridges. Leaves opposite-decussate, sessile or very shortly petiolate, pairs isophyllous, blade obovate or obovate-elliptic; cystoliths present, shortly linear, numerous but often inconspicuous. Inflorescences axillary, sessile or shortly pedunculate fasciculate cymes of $(1-) 2-3$ flowers, bracts and bracteoles paired, linear-lanceolate, green with hyaline margins. Calyx shortly tubular, deeply
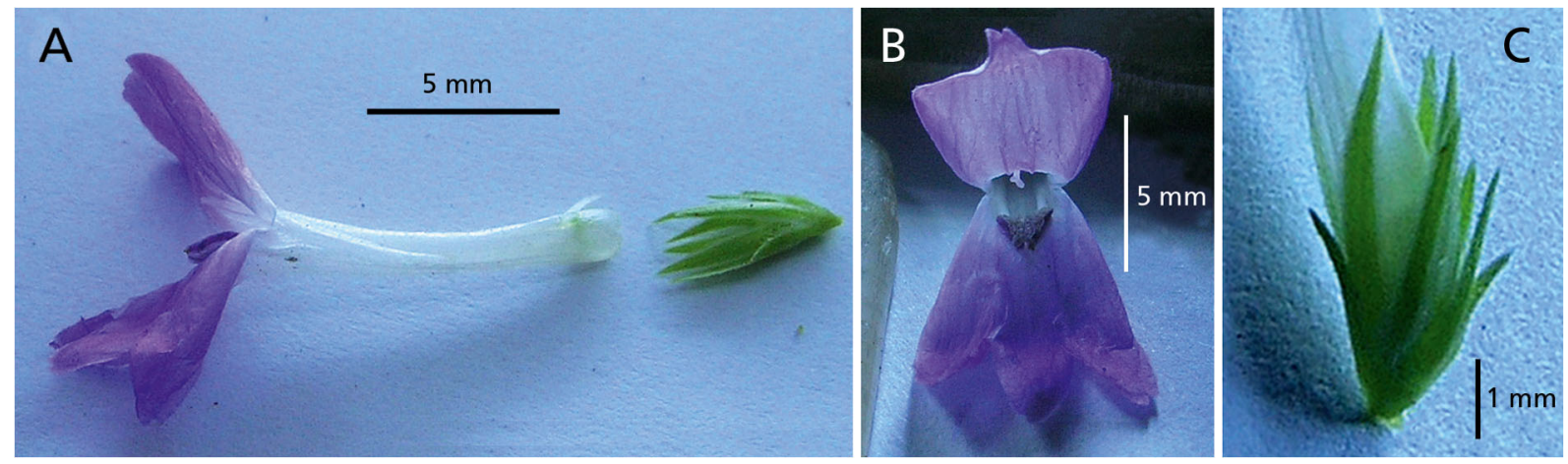

Fig. 8. Kenyacanthus ndorensis. A flower, lateral view; B flower, face view; C bracts, bracteoles and calyx with corolla base (photographed from plant cultivated by W. R. Q. Luke). 
divided into five lobes, these subequal, linearlanceolate with hyaline margins, shorter than the bracteoles. Corolla with rugula present, comprising two slender ciliate ridges extending from near base of corolla tube to proximal portion of upper lip; tube slender, longer than limb, gradually widened towards the mouth; aestivation ascending-cochlear, limb bilabiate; upper lip ovate or elliptic, apex shortly bilobed or emarginate, lower lip conspicuously 3-lobed, palate with faint raised venation. Stamens 2, inserted on ventral side of corolla tube just below the corolla mouth; filaments short; anthers shortly exserted, held \pm adpressed to the lower lip, dehiscing toward upper lip (i.e. flowers stenotribic), bithecous, thecae \pm parallel, slightly offset, lacking basal appendages; staminodes absent. Floral disk cupular, $\pm 0.5 \mathrm{~mm}$ tall, with unevenly undulate margin. Ovary oblong-ellipsoid, 4-ovulate; style filiform; stigma minutely bilobed, one lobe slightly larger than the other. Capsule 4seeded (or fewer by abortion), retinaculate, stipitate and with attenuate apex; seeds tuberculate.

RECOGNITION. Kenyacanthus is recognised by having the combination of a trailing or procumbent habit; fasciculate inflorescences; bracts, bracteoles and calyces with hyaline margins; a bilabiate corolla with a slender cylindrical tube longer than the limb and with a shallow rugula; and two stamens held against the lower corolla lip and anthers with slightly offset thecae, the flowers being stenotribic. It differs from Rhinacanthus primarily in the trailing or procumbent habit; hyaline margins to the bracts, bracteoles and calyx lobes; two corolla lips of subequal size; stenotribic flowers and essentially glabrous capsules (vs plants erect, decumbent or straggling; bracts etc. lacking hyaline margins; upper corolla lip markedly smaller and narrower than the lower lip; flowers nototribic and capsules puberulous to pubescent in Rhinacanthus). It differs from Dicliptera primarily in the combination of a straight, untwisted corolla tube and stenotribic flowers (vs corolla tube twisted through \pm $180^{\circ}$ such that the corolla is resupinate, or if corolla tube untwisted then flowers nototribic in Dicliptera); it also differs from all African Dicliptera in the anther thecae being only partially offset (vs fully superposed).

ETYMOLOGY. Kenyacanthus is named in honour of the Republic of Kenya, to which this genus is apparently endemic based on current evidence.

\section{Kenyacanthus ndorensis (Schweinf.) I.Darbysh. Eे C.A.Kiel comb. nov.}

http:/ /www.ipni.org/urn:lsid:ipni.org:names:60478965-2

Rhinacanthus ndorensis Schweinfurth in Höhnel, Zum Rudolph-See und Stephanie-See: 858 (1892); Engler
(1892: 394), nom. nud.; Schweinfurth (1894: 357); Clarke (1900a, 1900b: 225); Mildbraed (1926: 504); Agnew (2013: 327, pl. 129C); Lebrun \& Stork (1997: $500)$ as "sont mal connus"; Darbyshire et al. (2010: 602). Type: Kenya, Ndoro, foot of Mt Kenya, fr. 1887 - 1888, Höhnel s.n. [Höhnel 76 per Engler 1892] (B† holotype; BM! [BM001011739] lectotype, selected here - see note); Nyeri County, NanyukiNaromoru, near pt. 866 (Ndoro?), fl. \& fr. 7 Feb. 2016, Luke 17084 (EA! epitype, selected here; $\mathrm{K}$ ! isoepitype).

Procumbent or trailing perennial herb, branching widely from a small woody base and rootstock, forming small mats in the ground layer; young stems with two prominent pairs of opposite ridges and two broader opposite ridges, glabrous except for tufts of multicellular trichomes along the nodal lines. Leaves sessile or on a poorly defined petiole to $3 \mathrm{~mm}$ long; blade fleshy, obovate (-elliptic), $0.8-1(-1.4) \times 0.45-0.6$ ($0.75) \mathrm{cm}$, base cuneate, margin entire, apex obtuse or rounded, surfaces glabrous except for minute trichomes along the margin; lateral veins $3(-4)$ pairs. Inflorescences axillary, fasciculate, (1 -) 2 - 3-flowered; peduncle $0-3 \mathrm{~mm}$ long, glabrous; bracts linearlanceolate, $5.5-9 \mathrm{~mm}$ long, green with narrow hyaline margin at least in the proximal half, ciliate with trichomes of variable length, midrib prominent abaxially, apex minutely apiculate; bracteoles resembling bracts but $5-8.5 \mathrm{~mm}$ long, more gradually narrowed towards apex, margin more conspicuously hyaline; flowers sessile. Calyx with short basal tube 0.7 - $0.8 \mathrm{~mm}$ long; lobes linear-lanceolate, $3.7-5.5 \mathrm{~mm}$ long, margins narrowly hyaline, ciliate, surfaces with sparse short ascending trichomes. Corolla (13 -) 15 $18.5 \mathrm{~mm}$ long, bright pink to mauve, rather densely retrorse-pubescent externally; tube (8-) $10-11 \mathrm{~mm}$ long, $1-1.5 \mathrm{~mm}$ in diam. centrally, widening somewhat towards mouth, with scattered minute glandular trichomes on internal surface, rugula of two raised lines of trichomes on dorsal side of tube and barely extending onto upper lip; lips widely divergent, upper lip suberect, ovate or elliptic, $5-7 \times 3-3.7 \mathrm{~mm}$, glabrous internally, apex shortly bilobed or emarginate; lower lip pendant, $6-$ $7.5 \mathrm{~mm}$ long, glabrous internally, lobes oblong, $2.5-3 \times$ $1.4-1.8 \mathrm{~mm}$, apices obtuse or rounded with irregular margins, median lobe slightly longer and narrower than lateral pair. Stamens with filaments $1.2-2.3 \mathrm{~mm}$ long, glabrous; anther thecae offset by $0.25-0.3 \mathrm{~mm}$, each theca 1 - $1.5 \mathrm{~mm}$ long, basally muticous. Pollen prolate, 3colporate, 6-pseudocolpate, polar diameter (P) $35-37$ $\mu \mathrm{m}$, equatorial diameter $(\mathrm{E}) 20-22.5 \mu \mathrm{m}, \mathrm{P}: \mathrm{E}=1.57-1.8$, ora \pm the same width as the colpi, the pseudocolpi parallel to the colpi, interaperatural exine reticulate. Ovary \pm $1.5 \mathrm{~mm}$ long, glabrous; style $\pm 8.5 \mathrm{~mm}$ long, \pm sparsely appressed-pubescent or glabrous. Capsule 8-10 mm long, 


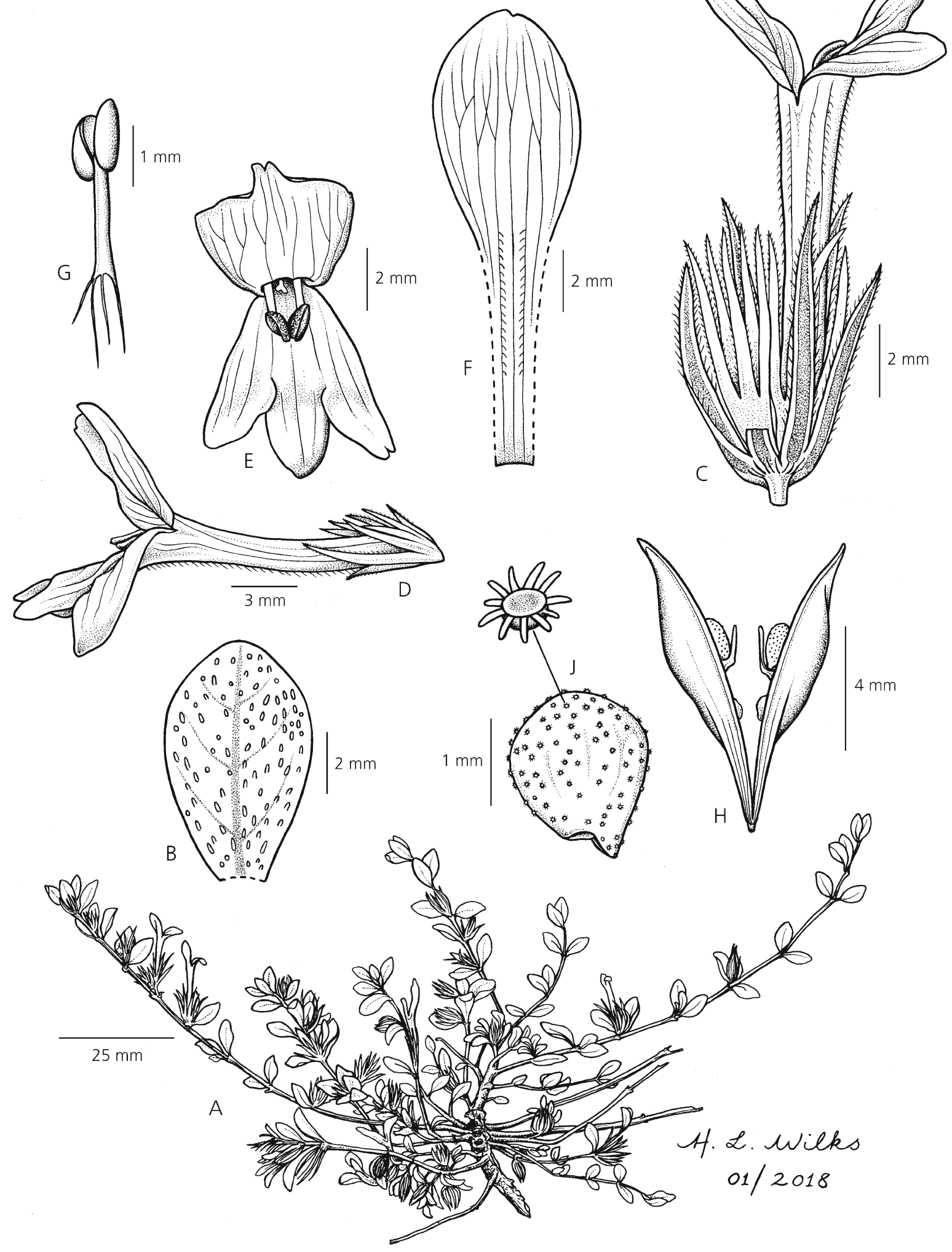

Fig. 9. Kenyacanthus ndorensis. A habit; B leaf, adaxial surface with cystoliths; C inflorescence, with one bracteole cut away at base to show the calyx; D flower, lateral view; E flower, face view showing position of stamens; F upper lip and dorsal side of corolla tube, showing the rugula; G stamen; $\mathrm{H}$ capsule; J seed, with detail of one tubercle. Drawn from Battiscombe 721 except J from Luke 17084 and D \& E from photos. by W. R. Q. Luke. DRAWN BY HAZEL WILKS. 
glabrous or with very few inconspicuous trichomes towards apex; seeds blackish at maturity, $1.3-1.8 \mathrm{~mm}$ in diameter, tuberculate, the tubercles short, rounded with minute glochidia. Figs. 8, 9 and 10.

DISTRIBUTION. Kenya (Laikipia and Nyeri Counties; Flora of Tropical East Africa floristic regions K3 and K4); Map 2.

SPECIMENS EXAMINED. KENYA. Unplaced: West Kenya plains, fl. \& fr. 29 July 1913, Battiscombe 721 (K! 2 sheets, EA photo!). Laikipia County: Rumuruti, NE slope Aberdare Mts, fl., without date [received at K: 22 Sept. 1915], Dowson 561 (EA!, K!); Nanyuki, fl. May 1932, Napier 2093 (EA!); Solio Ranch, 20 miles SW of Nanyuki, fl. 4 April 1973, Elliott 33 (EA!); Laikipia Distr., Rumuruti, fl. \& fr. 5 Nov. 1978, Hepper Ẽ Jaeger 6626 (EA!, K!); Mpala, 1800 m, fl. \& fr. 5 Nov. 1992, Young 3169 (EA!); Laikipia Distr., Nanyuki, Batuk, Laikipia Airbase, $5 \mathrm{~km}$ NW Nanyuki town, fl. 18 March 2010, Malombe E Kimeu BATUK 1594 (EA!). Nyeri County: Ndoro, foot of Mt Kenya, fr. 1887 - 1888, Höhnel s.n. (BM! lectotype); Cole’s Mill, fl. 17 Jan. 1922,
Fries 1001 (BM!); Nyeri, Amboni R., fl. \& fr. 18 Jan. 1933, Napier 2579 (EA!, K!); Nanyuki, fl. Dec. 1933, Minns s.n. [in Coryndon Museum 5881] (EA!); 3 miles SE Nanyuki Station, fl. 19 June 1943, Moreau E Moreau 34 (EA!); North Nyeri Distr., Nyeri to Nanyuki, c. 40 km S Nanyuki, fl. 3 April 1975, Hepper E Field 4838 (K!); NanyukiNaromoru, near pt. 866 (Ndoro?), fl. \& fr. 7 Feb. 2016, Luke 17084 (EA! epitype, K! isoepitype).

HABITAT \& ECOLOGY. This species occurs in upland grassland and open woodland, including Acacia drepanolobium Harms ex Y.Sjöstedt woodland, where it can form small mats amongst the grasses in the ground layer of the vegetation (Fig. 10). These mats are conspicuous during the dry season, appearing green amongst the dried brown grasses (Odadi et al. 2013). It can also sometimes be found along road verges. It often grows on seasonally damp black clay soils; $1700-2150$ m elevation.

PHENOLOGY. From the limited information available, mainly derived from specimen data, this species appears to have a prolonged flowering season, recorded from early November through to late July. This

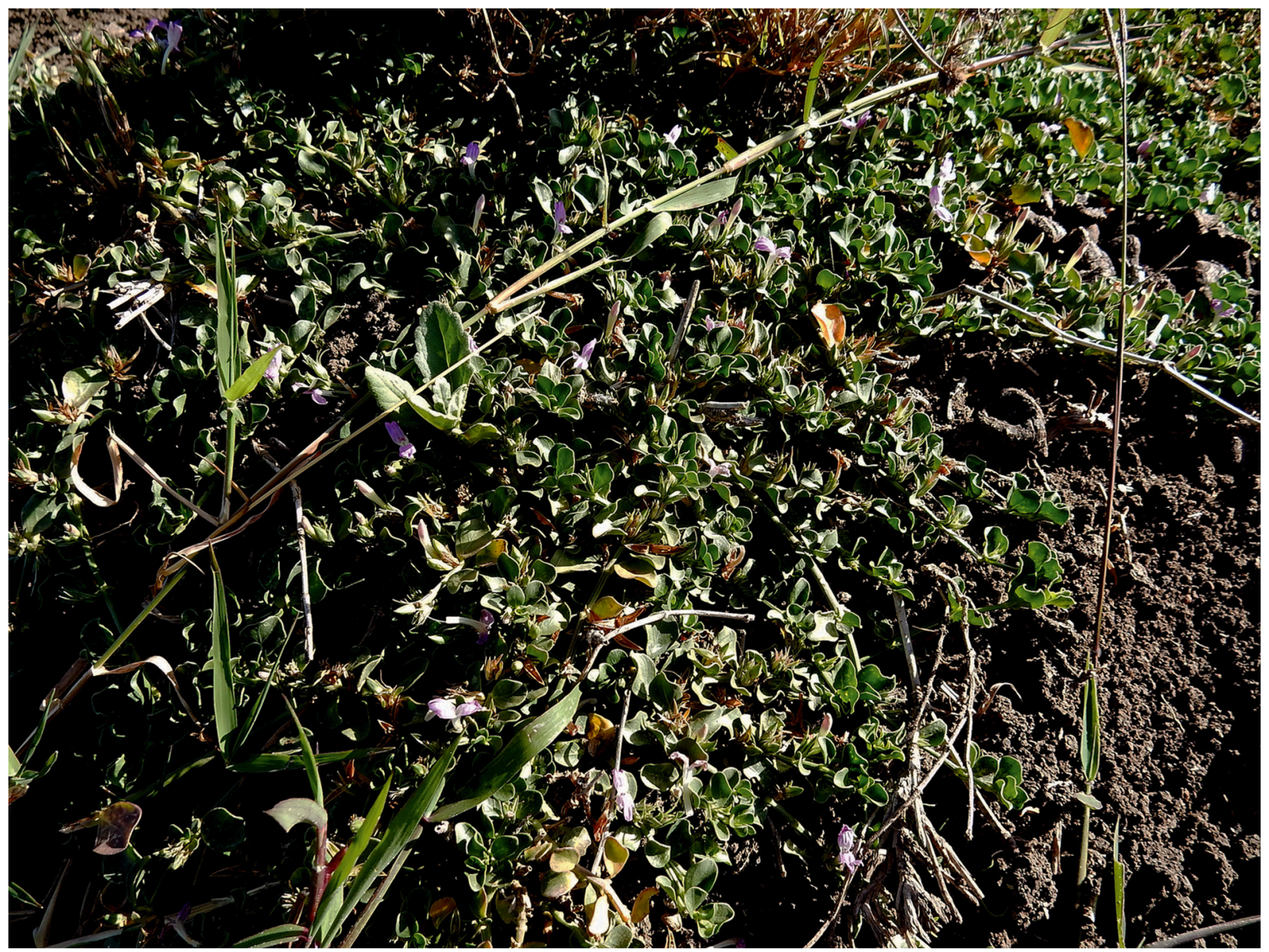

Fig. 10. Habit of Kenyacanthus ndorensis in the field, collected as Luke 17084. PHOTO: W. R. Q. LUKE. 


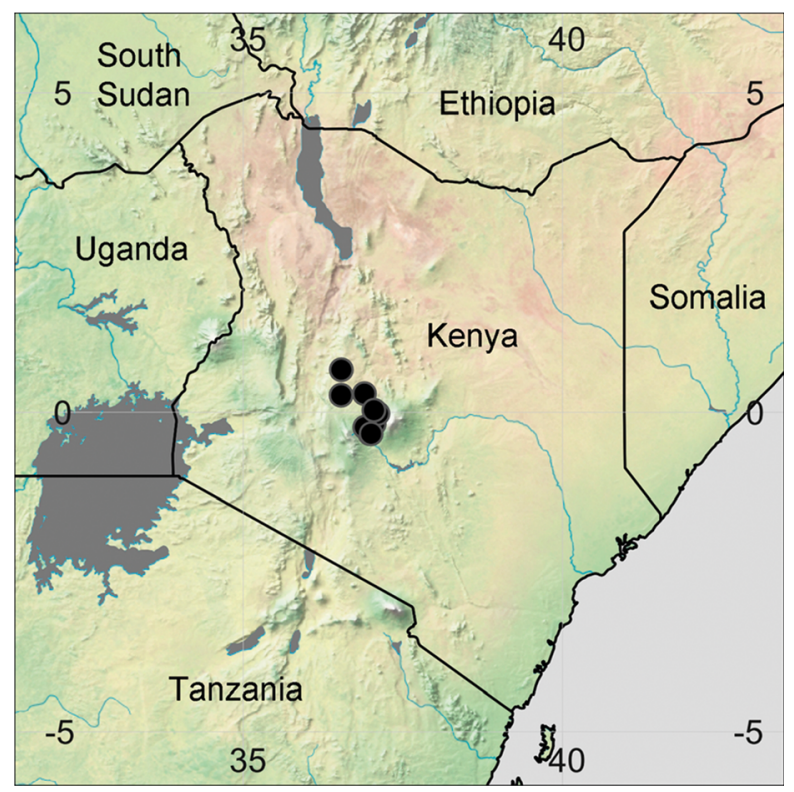

Map 2. Distribution of Kenyacanthus ndorensis (black circles).

spans the period of the two rains - the first rains occur primarily in October and November whilst the peak rains fall in April to May. The intervening period is dry, with January being the driest month.

CONSERVATION STATUS. Darbyshire et al. (2010) considered this species to be Near Threatened (NT) based on its very restricted range (the EOO is approx. $3050 \mathrm{~km}^{2}$ ), with few collections known, and with potential loss of habitat due to expansion of agriculture. It can be locally frequent to abundant in suitable habitat (W. R. Q. Luke, pers. obs.) and is regularly consumed by cattle as an important fodder during dry periods (Odadi et al. 2013). However, in some parts of its range it is threatened by widespread habitat loss through conversion to commercial pastoral agriculture and the global population is considered to be declining. This species has, therefore, recently been provisionally assessed as Endangered (EN Blab(ii,iii,iv)+2ab(ii,iii,iv)) by the East African Plant Red List Authority (W. R. Q. Luke et al., unpubl. data). This assessment is awaiting publication on the IUCN Red List. NOTES. From Fig. 8 and the discussion above, it is apparent that during at least a significant portion of anthesis (if not throughout) the stamens and anthers are held adjacent to the lower lip whereas the style and stigma are adjacent to the upper lip. This poses the question as to how pollen is transferred by pollinators from the anthers to the stigma, when these two organs are held on opposite sides of the corolla mouth. Field observations are required to document the position of the anthers and stigma throughout anthesis and also to document pollinator interactions in order to resolve this issue.

The author for Rhinacanthus ndorensis has sometimes been given as Schweinf. ex Engl. (e.g. see Klopper et al. 2006: 18). This is based on Engler
(1892: 394) who recorded "Rhinacanthus ndorensis Schweinf. nov. spec. msc." then cited the proposed type specimen, which he listed as v. Höhnel 76. However, the only description provided states "Gebüschpfl." (i.e. bushy plant), a phrase applied to multiple taxa within Engler's work and not considered to be sufficient to constitute a description as per Article 38.1 of the Botanical Code, hence Engler (1892) did not validly publish the name $R$. ndorensis. A short but sufficient description was provided by Schweinfurth (1892: 858) together with the type citation, which validated the name.

The extant material of the Höhnel type specimen at $\mathrm{BM}$ is only a very small scrap with a few leaves, an inflorescence and an immature fruit; the holotype specimen at B is believed to have been destroyed during World War II. An epitype is therefore selected to supplement the lectotype, and Luke 17084 is chosen as it was collected from a site near Naromoru which a local informant said had previously been known as 'Mukiri wa Ndoro' (translated as "valley of mud" in Kikuyu); this is quite likely to be the same as the Ndoro of the original type locality.

The general habit, of trailing stems with axillary (sub)sessile clusters of flowers, is superficially most reminiscent of trailing members of the genus Dyschoriste Nees which is distantly related, in tribe Ruellieae of Acanthaceae (Tripp et al. 2013). Indeed, both Mildbraed (1926) and Agnew (2013) remark upon this potential confusion. However, Dyschoriste is easily separated from Kenyacanthus in, amongst other differences, having a markedly tubular calyx, an androecium comprising 4 fertile stamens or 2 fertile stamens +2 staminodes, left-contorted corolla aestivation and seeds with hygroscopic trichomes.

\section{Acknowledgements}

We are highly indebted to Dominique Champluvier (formerly of BR) for providing useful information on the species of Champluviera treated here. We thank Hazel Wilks for the line drawings of Champluviera populifolia and Kenyacanthus ndorensis, and Martin Cheek and Jo Osborne (both $\mathrm{K}$ ) for allowing us to use their photographs of $C$. populifolia. Heather Lindon is thanked for her assistance with the nomenclatural history of Rhinacanthus ndorensis. Aurélie Grall (R.B.G. Kew) assisted with the SEM analysis of pollen grains of $R$. ndorensis and Hannah Armer (Manager of the Light Microscopy Imaging Suite, Natural History Museum, London) very kindly photographed the stamens of Champluviera nuda presented in Fig. 5. We thank the curators of the herbaria visited for providing access to the collections of the study taxa, notably Itambo Malombe (EA) and Ranee Prakesh (BM). Pulchérie Bissiengou kindly checked for specimens 
of J. tigrina at the LBV herbarium on our behalf and sent scanned images of Mayombo-Nzengue 271 which were very helpful. This work was supported by grants from the U.S. National Science Foundation to CAK (DEB1754845); TFD (DEB0743273, DEB 0108589, BSR 8304790) and LAM (DEB 9707693, DEB 0108589, DEB 0743178, DEB 1754845).

\section{Appendix 1}

Taxa, sources of plant materials from which DNA was extracted for sequencing and GenBank accession numbers (trnS-G, trnT-L, rps16, trnL-F, nrITS; - = sequence not obtained); when a given taxon is not depicted by name as a terminal in Figs. 1 or 2, the last entry indicates the clade where that taxon is placed in our results (clade names are as given in Figs 1 and 2). Taxa are listed in alphabetical order by genus and species. When plants in cultivation were used, we provide information on native range in parentheses. GenBank numbers beginning with MF and MK are new to this study.

Ancistranthus harpochiloides Lindau; Cuba, Shafer 13404 (US) MF670371, MF768291, MF678397, MF768343, MF768396; Tetramerium lineage. Angkalanthus oligophylla Balf.f.; Yemen (Socotra), Miller M10292 (UPS) EU081105, EU081172, EU087533, EU087567, EU087478; Tetramerium lineage. Anisacanthus gracewoodiae Hammel \& McDade; Costa Rica, Hammel et al. 26865 (RSA) MF670359, MF768281, MF678386, MF768327, MF768385; Tetramerium lineage. Anisotes formosissimus Milne-Redh.; cultivated, Lowveld National Botanical Garden, South Africa: Mpumalanga (native to South Africa), Daniel 9382 (CAS) KY584162, KY632232, MK282280, MK282352, KY632576; Old World justicioid lineages. Anisotes macrophyllus (Lindau) Heine; Uganda, Synnott 488 (EA) KY584141, KY632212, -, MK282353, MK282341; Old World justicioid lineages. Anisotes madagascariensis Benoist; Madagascar, Daniel E B Butterwick 6736 (CAS) KY584157, KY632227, MK282280, MK282354, AF289772; Old World justicioid lineages. Anisotes rogersii S.Moore; South Africa, McDade 1265 (J) KY584140, KY632211, MK282282, MK282355, KY632560; Old World justicioid lineages. Aphelandra leonardii McDade; Costa Rica, McDade 310 (DUKE) DQ059287, EU529071, DQ059205, AF063112, AF169761; outgroup.

Barleria lupulina Lindl.; cultivated, San Francisco Conservatory of Flowers, San Francisco, U.S.A. (native to Madagascar), Daniel s.n. (CAS) EU528946, EU529075, EU529010, AF289758, AF169751; outgroup. Brachystephanus africanus S.Moore; Tanzania, Luke et al. 6704 (US) DQ372491, DQ372446,
EU087537, MF768374, DQ372469; core Isoglossinae. Calycacanthus magnusianus K.Schum.; cultivated, Royal Botanic Gardens, Sydney (native to Papuasia), Daniel 10072 (CAS) EU081108, EU081175, EU087536, MK282356, EU087481. Thyrsacanthus sulcatus (Nees) C.Ezcurra \& A.L.A.Côrtes; Paraguay, Schinini Ẽ Bordas 18098 (MO) MF670373, MF768293, MF678398, MF768346, MF768399; Tetramerium lineage. Cephalacanthus maculatus Lindau; Peru, Veja E Dillon 8517 (F) KY584123, KY632195, KY632029, KY632353, KY632505, KY632545; New World justicioid lineage. Chlamydocardia buettneri Lindau; cultivated, National Botanic Garden of Belgium (native to Cameroun, Gabon, Ivory Coast and Nigeria), Accession No. 950034-44 (BR) EU081107, EU081174, EU087535, EU087569, EU087480; Tetramerium lineage. Chlamydostachya spectabilis Mildbr.; Poest Knox 88192/4 (K) KY584160, KY632230, MK282283, MK282357, KY632574; Old World justicioid lineages. Chorisochora transvaalensis (A.Meeuse) Vollesen; South Africa, Daniel 9379 (CAS) EU081100, EU081167, EU087528, EU087565, EU087474; Tetramerium lineage. Clinacanthus siamensis Bremek.; cultivated, National Botanic Garden of Belgium (native to Thailand), Accession No. 1979-0344 (BR) EU081106, EU081173, EU087534, EU087568, EU087479; Tetramerium lineage. Clistax brasiliensis Mart., Brazil, Lombardi 2257 (US) KY584112, KY632186, MK282284, MK282358, KY632537; New World justicioid lineage. Conocalyx laxus Benoist; Madagascar, Leandri 3033 (P); DQ372485, DQ372440, -, MK282359, MK282342; core Isoglossinae.

Dicliptera extenta S.Moore; South Africa, McDade 1306 (J) EU528955, EU529084, EU529018, AF289724, KC420542; Dicliptera s.l. Dicliptera insularis Benoist; Madagascar, Daniel 9194 (CAS) KY584194, -, MK282285, AF289723, AF289764; Dicliptera s.1. Dicliptera magaliesbergensis K.Balkwill; South Africa, Daniel 9357 (CAS) KY584192, MK282273, -, AF289725, KY632607; Dicliptera s.l. Dicliptera resupinata Juss.; United States, Boyd s.n. (ARIZ); KY584189, EU529084, EU529019, MK282360, AF169841; Dicliptera s.l. Dicliptera suberecta (André) Bremek., cultivated, University of Arizona (native to Argentina, Bolivia, Paraguay), McDade 1176 (ARIZ) KY584188, KY632257, MK282286, AF289722, AF289763; Dicliptera s.l.

Henrya insularis Nees ex Benth; Mexico, Jenkins 89-432 (ARIZ) EU081071, EU081142, EU087507, AF063125, AF169843; Tetramerium lineage. Hoverdenia speciosa Nees; Mexico, Daniel E B Baker 3739 (CAS) EU081089, EU081157, EU087519, AF289738, AF289777; Tetramerium lineage. Hypoestes sp.; Madagascar, Daniel E McDade 10433 (CAS) KY584203, KY632274, MK282287, MK282361, -; Hypoestes clade. Hypoestes 
aristata (Vahl) Sol. ex Roem. \& Schult.; cultivated, San Francisco Conservatory of Flowers (East Africa, South Africa, Madagascar), Daniel s.n. (CAS) KY584208, KY632279, MK282288, AF289726, KY632625; Hypoestes clade. Hypoestes phyllostachya Baker, cultivated University of Arizona (widespread in OW tropics), McDade 1232 (ARIZ) KY584207, KY632278, EU529025, AF195520, AF169842; Hypoestes clade.

Isoglossa gracillima Baker; Madagascar, Daniel 9106 (CAS) DQ372488, DQ372443, MK282289, AF289746, AF289789; core Isoglossinae. Isoglossa grandiflora C.B.Clarke; Cultivated, San Francisco Conservatory of Flowers, San Francisco, CA, U.S.A. (Malawi, Tanzania, Zambia), Daniel s.n. (CAS) DQ372490, DQ372445, MK282290, AF289745, AF289788; core Isoglossinae. Isoglossa ovata (Nees) Lindau; South Africa, Daniel 9336 (CAS) DQ372487, DQ372442, EU529027, MK282362, DQ372468; core Isoglossinae.

Jadunia biroi (Lindau \& K.Schum.) Lindau, Papua New Guinea, Daniel et al. 6603 (CAS) MK282333, MK282274, MK282291, MK282363, MK282343. Justicia sp.; Cameroon, Tchiengue 2518 (K) MK282268, MK282269, MK282270, MK282271, MK282344. Justicia sp.; Madagascar, Daniel 9024 (CAS) KY584182, KY632251, MK282292, AF289729, AF289768; Old World justicioid lineages. Justicia sp.; Madagascar, Daniel et al. 10446 (CAS) KY584138, KY632210, MK282293, MK282365, KY632559; Old World justicioid lineages. Justicia aconitiflora (A.Meeuse) Cubey; cultivated, San Francisco Conservatory of Flowers (native to South Africa), Daniel et al. 9361 (CAS) KY584161, KY632231, MK282294, AF289735, AF289774; Old World justicioid lineages. Justicia adhatoda L.; cultivated, University of Arizona (native to South Africa), Barr 60-393 (ARIZ) KY584158, EU081109, DQ059214, AF289734, AF289773; Old World justicioid lineages. Justicia americana (L.) Vahl; United States, Daniel E Lott 10530 (CAS) KY584096, KY632173, MK282295, MK282366, KY632522; New World justicioid lineage. Justicia anagalloides (Nees) T.Anderson; cultivated NBI Garden, South Africa (native to Africa), McDade $\mathcal{E}$ Balkwill 1239 (J) KY584151, KY632221, MK282296, MK282367, MK282345; Old World justicioid lineages. Justicia andromeda (Lindau) J.C.Manning \& Goldblatt; South Africa, Balkwill et al. 11660 (J) KY584146, KY632216, MK282297, MK282368, KY632563; Old World justicioid lineages. Justicia anselliana (Nees) T.Anderson; Tanzania, Kiel et al. 155 (RSA) KY584181, KY632250, MK282298, MK282369, KY632594; Old World justicioid lineages. Justicia betonica L.; cultivated, Johannesburg, Gauteng, South Africa (widespread tropical Africa), Daniel 9369 (CAS) KY584165, KY632235, MK282299,
AF289731, AF289770; Old World justicioid lineages. Justicia bolusii C.B.Clarke; cultivated, South Africa (native to South Africa), Balkwill s.n. (J) KY584246, KY632313, -, -, KY632656. Justicia brandegeeana Wassh. \& L.B.Sm.; cultivated, University Arizona (native to Mexico), Starr c. 32 (ARIZ) KY584130, KY632203, MK282300, MK282370, KY632553; New World justicioid lineage. Justicia brasiliana Roth; Paraguay, Zardini E Aguayo 9523 (CAS) KY584118, KY632190, MK282301, MK282371, KY632542; New World justicioid lineage. Justicia cavernarum F.Muell.; Australia, Forster 28601 (CAS) KY584143, KY632214, MK282302, MK282372, KY632562; Old World justicioid lineage. Justicia comata (L.) Lam.; Costa Rica, Kiel E $\mathcal{F}^{\circ}$ McDade 138 (CAS) KY584088, KY632165, MK282303, MK282373, KY632515; New World justicioid lineage. Justicia flava (Forssk.) Vahl; South Africa, McDade et al. 1256 (J) KY584235, KY632302, MK282304, MK282374, KY632648; Harnieria \& Tyloglossa clades. Justicia gendarussa Burm.f.; cultivated, San Francisco Conservatory of Flowers (native to tropical Asia), Daniel s.n. (CAS) KY584166, KY632236, MK282305, MK282375, KY632580; Old World justicioid lineages. Justicia grossa C.B.Clarke; Thailand, Von Bousekom E Santisuk 2699 (L) KY584171, KY632241, MF678390, MF768371, KY632585; Tetramerium lineage. Justicia hassleri (Lindau) V.A.W.Graham; Bolivia, Wood 19750 (CAS) KY584131, KY632204, MK282306, MK282376, KY632554; New World justicioid lineage. Justicia hyssopifolia L.; cultivated Kew 1991-1486 (native to Canary Islands) (K) KY584250, KY632317, MK282307, MK282377, KY632659; Old World justicioid lineages. Justicia linifolia (Lindau) V.A.W.Graham; South Africa, Balkwill 10860 (J) KY584238, KY632305, MK282308, MK282378, KY632651; Old World justicioid lineages. Justicia longii Hilsenb.; United States, Arizona, Van Devender 87-307 (ARIZ) KY584107, KY632182, MK282309, MK282379, KY632532; New World justicioid lineage. Justicia odora (Forrsk.) Lam.; South Africa, Daniel E Butterwick 9364 (CAS) KY584241, KY632308, MK282310, MK282380, KY632653; Harnieria \& Tyloglossa clades. Justicia pacifica Hemsl.; Mexico, Kiel et al. 74 (RSA) KY584103, KY632179, MF678421, MF768367, KY632529; New World justicioid lineage. Justicia prominens Benoist; Laos, Klackenberg 1383 (S) KY584177, KY632246, MF678395, MF768370, KY632590; Tetramerium lineage. Justicia rhodoptera Baker; Madagascar, Daniel E $\mathcal{E}$ Butterwick 6741 (CAS) KY584136, KY632208, MK282272, MK282381, KY632557; Old World justicioid lineages. Justicia ruwenzoriensis C.B.Clarke; Zaire, de Witte 2862 (CAS) KY584164, KY632234, MK282311, MK282382, KY632578; Old World justicioid lineages. Justicia 
vagabunda Benoist; China, Tripp 1547 (COLO) MK282334, MK282275, MK282312, MK282383, -.

Lepidagathus formosensis C.B.Clarke ex Hayata; Taiwan, Bartholomew et al. 7654 (CAS) EU528973, EU529101, EU529034, EU528930, EU529101; outgroup.

Marcania grandiflora J.B.Imlay; Thailand, Van Beusekom et al. 3985 (L) MK282335, MK282276, MK282313, MK282384, MK282346. Megalochlamys revoluta (Lindau) Vollesen; South Africa, McDade E Balkwill 1264 (J) EU081099, EU081166, EU087527, EU087564, EU087473; Tetramerium lineage. Megaskepasma erythrochlamys Lindau; Costa Rica, Hammel et al. 26088 (RSA) KY584120, KY632192, MK282314, MK282385, KY632544; New World justicioid lineage. Metarungia galpinii (Baden) Baden; cultivated, Johannesburg, Gauteng, South Africa (native to South Africa), Daniel 9322 (CAS) KY584168, KY632238, EU529046, AF289737, KY632582; Old World justicioid lineages. Metarungia longistrobus Baden; cultivated, Witwatersrand National Botanic Garden, Roodepoort, South Africa (native to South Africa), Daniel et al. 9355 (CAS) KY584169, KY632239, MK282315, MK282386, KY632583; Old World justicioid lineage. Mirandea huastecensis T.F.Daniel; Mexico, Manktelow 706 (UPS) EU081099, EU081166, EU087527, EU087564, EU087473: Tetramerium lineage. Monechma divaricatum C.B.Clarke; South Africa, McDade 1275 (J) KY584209, KY632280, MK282316, MK282387, KY632626; Monechma II clade. Monechma divaricatum C.B.Clarke; South Africa, Daniel et al. 9373 (CAS) KY584210, KY632281, MK282317, MK282388, KY632627; Monechma II clade. Monechma mollissimum P.G.Mey.; South Africa, Balkwill et al. 11787 (J) KY584211, KY632282, MK282318, MK282389, KY632628; Monechma II clade. Monothecium aristatum (Nees) T.Anderson; Tanzania, Abdallah et al. 512 (US) MK282336, MK282277, MK282319, MK282390, MK282348. Monothecium glandulosum Hochst.; Ethiopia, Friis et al. 9498 (C) MK282337, MK282278, MK282320, MK282391, MK282347.

Odontonema tubaeforme (Bertol.) Kuntze; cultivated Duke University greenhouse (native to Mexico and Central America), McDade 1182 (ARIZ) KY584172, DQ372462, DQ059215, AF063127, AF169748;

Pseuderanthemum lineage.

Pachystachys lutea Nees; cultivated, Duke University greenhouse (native to Peru), McDade 1181 (DUKE) EU081082, EU081151, EU087516, AF063128, AF169844; Tetramerium lineage. Peristrophe brassii R.M.Barker; Australia, Forster 28600 (CAS) KY584201, KY632272, MK282321, MK282392, KY632618; Dicliptera s.l. Peristrophe hyssopifolia (Burm.f.) Bremek., cultivated, Missouri Botanical Garden, St. Louis, Missouri, U.S.A., MBG861410 (native to Indonesia), MacDougal 5047
(MO) KY584202, KY632273, MK282322, MK282393, KY632620; Dicliptera s.1. Peristrophe speciosa (Roxb.) Nees, cultivated San Francisco Conservatory of Flowers (native to Asia), Daniel s.n. (CAS) KY584200, KY632271, MK282323, MK282394, KY632617; Dicliptera s.l. Poikilacanthus macranthus Lindau; Costa Rica, Kiel et al. 85 (RSA) KY584127, KY632200, MK282324, MK282395, KY632550; New World justicioid lineage. Populina richardii Baill.; Madagascar, Kerardren 1671 (P) EU081104, EU081171, EU087532, EU087566, EU087477; Tetramerium lineage. Pseuderanthemum floribundum T.F.Daniel; cultivated, San Francisco Conservatory (native to Mexico), Daniel 5381cv (CAS) KY584173, -, MK282325, MK282396, DQ37247; Pseuderanthemum lineage. Ptyssiglottis psychotriifolia (Stapf) B.Hansen; Borneo, Poulsen 40 (C) DQ372484, DQ372439, MK282326, MK282397, DQ372466. Ptyssiglottis pubisepala (Lindau) B.Hansen; Papua New Guinea, Daniel 6630 (CAS) DQ372483, DQ372438, EU529055, AF289744, AF289787.

Razisea spicata Oerst; Costa Rica, Hammel 7974 (DUKE) DQ372502, DQ372457, EU529056, AF063131, AF169848; core Isoglossinae. Rhinacanthus angulicaulis I.Darbysh.; Kenya, Kiel et al. 170 (RSA) KY584226, KY632293, -, -, KY632639; core Rhinacanthus. Rhinacanthus dichotomus (Lindau) I.Darbysh. var. dichotomus; Tanzania, Mfinanga 17 (US) KY584223, KY632290, -, -, KY632636; core Rhinacanthus. Rhinacanthus latilabiatus (K.Balkwill) I.Darbysh.; cultivated San Francisco Conservatory of Flowers (native to South Africa), Daniel s.n. (CAS) KY584222, KY632289, MK282327, MK282398, KY632635; core Rhinacanthus. Rhinacanthus nasutus (L.) Kuntze; Thailand, Nanakorn 880081 (US) KY584229, KY632296, -, -, KY632642; core Rhinacanthus. Rhinacanthus ndorensis Schweinf.; Kenya, Yoong 3169 (EA) KY584221, KY632288, -, -, -. Rhinacanthus ndorensis Schweinf.; Kenya, Luke 17084 (EA) MK282338, MK282279, MK282328, MK282399, MK282349. Rhinacanthus pulcher Milne.Redh.; Kenya, Gilbert E $\mathcal{F}^{\text {Thulin }} 1081$ (EA) KY584225, KY632292, -, -, KY632638; core Rhinacanthus. Rhinacanthus rotundifolius C.B.Clarke; Kenya, Luke et al. TPR60 (EA) KY584227, KY632294, -, -, KY632640; core Rhinacanthus. Rhinacanthus virens (Nees) Milne-Redh.; Uganda, Lye 3875 (EA) KY584220, -, -, -, KY632634. Rhinacanthus xerophilus A.Meeuse; South Africa, McDade 1277 (J) KY584224, KY632291, MK282329, MK282400, KY632637; core Rhinacanthus. Ruellia californica (Rose) I.M.Johnst.; Cultivated, Univ. Arizona campus, Tucson, Arizona, U.S.A. (native to northwest Mexico), McDade 1157 (ARIZ) EU528996, EU529123, EU529058, AF063115, AF167704; outgroup. Rungia klossii S.Moore; Papua New Guinea, Daniel et al. 6561 (CAS) KY584170, KY632240, MK282330, MK282401, KY632584; Old World justicioid lineages.

Schaueria gonatistachya Nees; Brazil, Paixao et al. 67 (CAS) MF670378, MF768297, MF678389, MF768352, 
MF768404; Tetramerium lineage. Schaueria populifolia C.B.Clarke; Cameroon, Gereau et al. 5666 (MO) MF670388, MF768309, MF678381, MF768372, MF768415. Schaueria populifolia C.B.Clarke; Cameroon, Cheek 10153 (K) MK282339, -, -, MK282402, MK282351. Schaueria populifolia C.B.Clarke; Cameroon, Manning 1336 (K) MK282340, -, -, MK282403, MK282350.

"Tetramerium lineage" indet.; Malaysia, Hansen $\mathcal{E}$ Smitinand 12005 (L) MF670389, MF768307, MF678404, MF768368,-; Tetramerium lineage. Tetramerium nervosum Nees; United States, McDade $\mathcal{E}^{2}$ Jenkins 1154 (ARIZ) EU081058, EU081126, EU087493, AF063133, AF169847; Tetramerium lineage. Trichocalyx obovatus Balf.f.; Socotra, Yemen, Thulin E $\mathcal{F}^{2}$ Gifri 8503 (UPS) KY584176, KY632245, MK282331, MK282404, KY632589; Harnieria \& Tyloglossa clades. Xerothamnella herbacea C.T.White; Australia, Daniel 10066 (CAS) KY584204, KY632275, MK282332, MK282405, KY632621; Dicliptera s.l.

Open Access This article is distributed under the terms of the Creative Commons Attribution 4.0 International License (http://creativecommons.org/ licenses/by/4.0/), which permits unrestricted use, distribution, and reproduction in any medium, provided you give appropriate credit to the original author(s) and the source, provide a link to the Creative Commons license, and indicate if changes were made.

\section{References}

Agnew, A. D. Q. (2013). Upland Kenya Wild Flowers and Ferns. Third Edition. Nature Kenya - the East African Natural History Society, Nairobi.

Akaike, H. (1974). Automatic control: A new look at the statistical model identification. IEEE T. Biomed. Eng. 19: 716 - 723.

Bachman, S., Moat, J., Hill, A. W., de la Torre, J. \& Scott, B. (2011). Supporting red list threat assessments with GeoCAT: Geospatial conservation assessment tool. ZooKeys 150: 117 - 126.

Balkwill, K., Getliffe-Norris, F. \& Balkwill, M.-J. (1996). Systematic studies in the Acanthaceae; Dicliptera in southern Africa. Kew Bull. 51: 1 - 61 .

\& Welman, W. G. (2000). Acanthaceae. In: O. A. Leistner (ed), Seed Plants of Southern Africa: Families and Genera. Strelitzia 10, 34 - 45. National Botanical Institute, Pretoria.

Cable, S. \& Cheek, M. (1998). The Plants of Mount Cameroon. A Conservation Checklist. Royal Botanic Gardens, Kew.

Champluvier, D. \& Darbyshire, I. (2009). A revision of the genera Brachystephanus and Oreacanthus (Acanthaceae) in tropical Africa. Syst. Geogr. Pl. 79: 115 - 192 .
Cheek, M., Pollard, B. J., Darbyshire, I., Wild, C. \& Onana, J.-M. (2004). The Plants of Mwanenguba, Mt Kupe and the Bakossi Mts, Cameroon. A Conservation Checklist. Royal Botanic Gardens, Kew.

Clarke, C. B. (1900a). Schaueria. In: W. T. ThiseltonDyer (ed.), Flora of Tropical Africa, Vol. 5: 242. L. Reeve \& Co., London.

(1900b). Chlamydocardia. In: W. T. Thiselton-Dyer (ed.), Flora of Tropical Africa, Vol. 5: 234 - 235. L. Reeve \& Co, London.

Côrtes, A. L. A., Daniel, T. F. \& Rapini, A. (2016). Taxonomic revision of the genus Schaueria (Acanthaceae). Pl. Syst. Evol. 302: 819 - 851.

Daniel, T. F. (1995a). Revision of Odontonema (Acanthaceae) in Mexico. Contr. Univ. Michigan Herb. 20: 147 - 171.

(1995b). Acanthaceae. In: D. E. Breedlove (ed.), Flora of Chiapas, Pt. 4. The California Academy of Sciences, San Francisco.

(2009). Synopsis of Dicliptera (Acanthaceae) in the Nueva Galicia Region of Western Mexico with a new species, D. novogaliciana. Proc. Calif. Acad. Sci. Ser. 4(60): 1 - 18.

(2015). Odontonema aliciae, a new heterostylous species of Acanthaceae from Panama. Proc. Calif. Acad. Sci. Ser. 4(62): 25 - 30.

(2017). New and reconsidered Mexican Acanthaceae XII. Proc. Calif. Acad. Sci. 64: 131 154.

\& Figueiredo, E. (2009). The California Academy of Sciences Gulf of Guinea Expeditions (2001, 2006, 2008). VII. Acanthaceae of São Tomé and Príncipe. Proc. Calif. Acad. Sci. Ser. 4(60): 623 - 674.

McDade, L. A., Manktelow, M. \& Kiel, C. A. (2008). The "Tetramerium Lineage" (Acanthaceae: Acanthoideae: Justicieae): Delimitation and intralineage relationships based on $\mathrm{cp}$ and nrlTS sequence data. Syst. Bot. 33: $416-436$.

Darbyshire, I. (2009). Notes on the genus Dicliptera (Acanthaceae) in Eastern Africa. Kew Bull. 63: 361 - 383. \& Govaerts, R. (2017). A synopsis of Chlamydocardia (Acanthaceae) including Linocalix. Kew Bull. 72: 37 (5 pages).

\& Goyder, D. J. (2019). Notes on Justicia sect. Monechma (Acanthaceae) in Angola, including two new species. Blumea 64: 97 - 107. https://doi.org/ 10.3767/blumea.2019.64.02.01.

\& Harris, T. (2006). Notes on the genus Rhinacanthus (Acanthaceae) in Africa with a synopsis of the $R$. nasutus- $R$. gracilis complex and a key to the African members of the genus. Kew Bull. 61: $401-418$.

Nanyeni, L., Chase, F. M. \& Gonçalves, F. M. P. (2018). A synopsis of Rhinacanthus (Acanthaceae) in Angola and Namibia. Kew Bull. 73: 21 (12 pages).

Pearce, L. \& Banks, H. (2012). The genus Isoglossa (Acanthaceae) in west Africa. Kew Bull. 66: $425-439$. 
\& Vollesen, K. (2007). The transfer of the genus Peristrophe to Dicliptera (Acanthaceae) with a new species described from eastern Africa. Kew Bull. 62: 119 - 128. , Vollesen, K. \& Ensermu Kelbessa. (2010). Acanthaceae (Part 2). In: H. J. Beentje (ed.), Flora of Tropical East Africa. Royal Botanic Gardens, Kew.

Darriba, D., Taboada, G. L. \& Posada, D. (2012). JModelTest 2: More models, new heuristics and parallel computing. Nat. Methods 9: 772.

Doyle, J. J. \& Doyle, J. L. (1987). A rapid DNA isolation procedure for small amounts of fresh leaf tissue. Phytochem. Bull. 19: 11 - 15.

Engler, A. (1892). Über die Hochgebirgsflora des tropischen Afrika. Abh. Königl. Akad. Wiss. Berlin 1891, Abh. II: 1 - 461.

Ensermu Kelbessa. (2003). Two new species of Acanthaceae from NE tropical Africa and Arabia. Kew Bull. 58: 703 - 712.

Figueiredo, E. \& Keith-Lucas, M. (1996). Pollen morphology of Brachystephanus (AcanthaceaeJusticieae). Grana 35: 65 - 73.

Graham, V. A. W. (1988). Delimitation and infrageneric classification of Justicia (Acanthaceae). Kew Bull. 43: 551 - 624.

Hansen, B. (1992). The genus Ptyssiglottis (Acanthaceae). A taxonomic monograph. Opera Bot. 116: $1-58$.

Heine, H. (1963). Acanthaceae. In: F. N. Hepper (ed.), Flora of West Tropical Africa, Ed. 2, Vol. 2: 391 - 432. The Crown Agents for Overseas Governments and Administrations, London.

(1966). Acanthacées. In: A. Aubreville (ed.), Flore du Gabon, Vol. 13: 3 - 250. Museum National d'Histoire Naturelle, Paris.

Huelsenbeck, J. P. \& Ronquist, F. (2001). MrBayes: Bayesian inference of phylogenetic trees. Bioinformatics 17: $754-755$.

\& Ronquist, F., \& Hall, B. (2001). MrBayes: A program for Bayesian inference of phylogeny. Manual. http:// morphbank.ebc.uu.se/mrbayes/manual.php.

Hutchinson, J. \& Dalziel, J. M. (1931). Flora of West Tropical Africa. Vol. 2, Pt. 1. The Crown Agents for the Colonies, London.

IUCN (2012). IUCN Red List Categories and Criteria. Version 3.1. Second Edition. IUCN Species Survival Commission, Gland \& Cambridge.

Kiel, C. A., Daniel, T. F., Darbyshire, I. \& McDade, L. A. (2017). Unraveling relationships in the morphologically diverse and taxonomically challenging 'justicioid' lineage (Acanthaceae). Taxon 66: 645 - 675 .

, McDade, L. A., Daniel, T. F. \& Champluvier, D. (2006). Phylogenetic delimitation of Isoglossinae (Acanthaceae: Justicieae) and relationships among constituent genera. Taxon 55: 683 - 694.

Klopper, R. R., Chatelain, C., Bänninger, V., Habashi, C., Steyn, H. M., de Wet, B. C., Arnold, T. H., Gautier, L., Smith, G. E. \& Spichiger, R.
(2006). Checklist of the flowering plants of subSaharan Africa. An index of accepted names and synonyms. South African Botanical Diversity Network Report No. 42, SABONET, Pretoria.

Lebrun, J. P. \& Stork, A. L. (1997). Énumération des plantes à fleurs d'Afrique Tropicale. IV Gamopétales: Ericaceae à Lamiaceae. Conservatoire et Jardin Botaniques de la ville de Genève.

McDade, L. A., Daniel, T. F., Masta, S. E. \& Riley, K. M. (2000). Phylogenetic relationships within the Tribe Justicieae (Acanthaceae): evidence from molecular sequences, morphology, and cytology. Ann. Missouri Bot. Gard. 87: 435 - 458.

Daniel, T. F. \& Kiel, C. A. (2008). Toward a comprehensive understanding of phylogenetic relationships among lineages of Acanthaceae s.l. (Lamiales). Amer. J. Bot. 95: 1136 - 1152.

Daniel, T. F. \& Kiel, C. A. (2018). The Tetramerium Lineage (Acanthaceae, Justicieae) revisited: phylogenetic relationships reveal polyphyly of many New World genera accompanied by rampant evolution of floral morphology. Syst. Bot. 43: 97 - 116 .

Mildbraed, J. (1926). Acanthaceae. In: R. E. Fries \& T. C. E. Fries, Beiträge zur kenntnis der flora des Kenia, Mt Aberdare und Mt Elgon. VIII. Notizbl. Bot. Gart. Berlin-Dahlem 9: 485 - 522.

Morgan, D. R. \& Soltis, D. E. (1993). Phylogenetic relationships among members of Saxifragaceae sensu lato based on $r b c L$ sequence data. Ann. Missouri Bot. Gard. 80: 631 - 660.

Nees, C. G. (1839). Acanthaceae. In: H. R. Goeppert, J. K. Schauer \& J. C. Schauer (eds), Delectus Seminum in Horto Botanico Vratislaviensi Collectorum, pp. 1 - 3. Postmark, Breslau.

Odadi, W. O., Karachi, M. K., Abdulrazak, S. A. \& Young, T. P. (2013). Protein supplementation reduces non-grass foraging by a primary grazer. Ecol. Appl. 23: 455 - 463.

Onana, J. M. (2011). The vascular plants of Cameroon. A taxonomic checklist with IUCN assessments. Flore $d u$ Cameroun Vol. 39 "occasional volume". IRAD National Herbarium of Cameroon, Yaoundé.

(2013). Synopsis de especès végétales vasculaires endémiques et rares du Cameroun. Check-liste pour la gestation durable et la conservation de la biodiversité. In: J. M. Onana (ed.), Flore du Cameroun, Vol. 40. Ministère de la Recherche Scientifique et de l'Innovation (MINRESI), Yaoundé.

Posada, D. (2008). JModelTest: Phylogenetic model averaging. Molec. Biol. Evol. 25: 1253 - 1256.

\& Crandall, K. A. (2001). Selecting the best-fit model of nucleotide substitution. Syst. Biol. 50: $580-601$.

Rambaut, A., Suchard, M. A., Xie, D. \& Drummond, A. J. (2014). Tracer v. 1.6. http://beast.bio.ed.ac.uk/ Tracer. 
Ronquist, F. \& Huelsenbeck, J. P. (2003). MrBayes 3: Bayesian phylogenetic inference under mixed models. Bioinformatics 19: 1572 - 1574.

Schwartz, O. (1939). Flora des tropischen Arabien. Mitt. Inst. Allg. Bot. Hamburg 10: 1 - 393.

Schweinfurth, G. (1892). Phanerogamen. In: Appendix II, Aufzählung der wissenshcaftlichen Ergebnisse der Expedition, pp. 852 - 868. In: L. R. von Höhnel, Zum Rudolph-see und Stephanie-see. A. Hölder, Vienna.

(1894). Phanerogams. In: Appendix II, Abstract of the scientific results of the Expedition, pp. 350 - 368. In: L. von Höhnel, Discovery of lakes Rudolf and Stefanie: a narrative of Count Samuel Teleki's exploring and hunting expedition in eastern equatorial Africa in 1887 and 1888. Vol. 2. Longmans, Green \& co., London.

Stamatakis, A. (2014). RAxML version 8: A tool for phylogenetic analysis and post-analysis of large phylogenies. Bioinformatics 30: 1312 - 1313.

Sosef, M. S. M. (2006). Acanthaceae. In: M. S. M. Sosef et al. (eds), Check-list des plantes vasculaires du Gabon / Checklist of Gabonese vascular plants. Scripta Bot. Belg. 35: $35-43$.
Dauby, G., Blach-Overgaard, A., van der Burgt, X., Catarino, L., Damen, T., Deblauwe, V., Dessein, S., Dransfield, J., Droissart, V., Duarte, M. C., Engledow, H., Fadeur, G., Figueira, R., Gereau, R. E., Hardy, O. J., Harris, D. J., de Heij, J., Janssens, S., Klomberg, Y., Ley, A. C., Mackinder, B. A., Meerts, P., van de Poe, J. L., Sonké, B., Stévart, T., Stoffelen, P., Svenning, J.-C., Sepulchre, P., Zaiss, R., Wieringa, J. J. \& Couvreur, T. L. P. (2017). Exploring the floristic diversity of tropical Africa. BMC Biology 15: 15.

Thiers, B. (2019) Index Herbariorum: a global directory of public herbaria and associated staff. New York Botanical Garden's Virtual Herbarium. http://sweetgum.nybg.org/science/ih/. Last accessed 25 Jan. 2019.

Tripp, E. A., Daniel, T. F., Fatimah, S. \& McDade, L. A. (2013). Phylogenetic relationships within Ruellieae (Acanthaceae), and a revised classification. Int. J. Plant Sci. 174: 97 - 137.

\section{Publisher's Note}

Springer Nature remains neutral with regard to jurisdictional claims in published maps and institu- 